\title{
A coupling of hydrologic and hydraulic models appropriate for the fast floods of the Gardon River basin (France)
}

\section{O. Laganier, P. A. Ayral, D. Salze, and S. Sauvagnargues}

Ecole des Mines d'Alès, Laboratoire de Génie de l'Environnement Industriel et des Risques Industriels et Naturels, Alès, France

Correspondence to: P. A. Ayral (pierre-alain.ayral@mines-ales.fr)

Received: 3 August 2013 - Published in Nat. Hazards Earth Syst. Sci. Discuss.: 6 September 2013

Revised: 9 September 2014 - Accepted: 23 September 2014 - Published: 5 November 2014

\begin{abstract}
Mediterranean catchments are regularly affected by fast and flash floods. Numerous hydrologic models have been developed, and allow modelling of these floods. However, these approaches often concern average-size basins of a few hundred $\mathrm{km}^{2}$. At larger scales $\left(>1000 \mathrm{~km}^{2}\right)$, coupling of hydrologic and hydraulic models appears to be an adapted solution. This study has as its first objective the evaluation of the performances of a coupling of models for flood hydrograph modelling. Secondly, the coupling results are compared with those of other modelling options. The aim of these comparisons is to clear up the following points. (1) Is a simplified routing model (lag and route) as efficient as a full hydraulic model for the modelling of hydrographs, in the intermediary downstream part of the stream? (2) Is adding lateral inflows necessary for all studied events? (3) What is the impact of the qualities of upstream hydrologic modelling feeding the coupling? The coupling combines the SCS-LR (Soil Conservation Service-lag-and-route) hydrologic model of the ATHYS platform and the MASCARET 1-D hydraulic model based on full Saint-Venant equations. It is applied to the Gardon River basin $\left(2040 \mathrm{~km}^{2}\right)$ in the south of France. For the seven studied events, the results of the coupling are satisfactory, the calculated Nash indexes varying between 0.61 and 0.97 . The comparisons with the other modelling options show the important role of the spatial distribution of rains during events: when rains are centered on the intermediary downstream part of the catchment, adding lateral inflows is necessary; when rains are more important in the upstream part, the quality of the hydrologic modelling upstream of the coupling has a strong impact. Furthermore, the
\end{abstract}

used coupling of models seems well adapted for water rising and flooded area forecasting. The future developments of the tool will concentrate on this point.

\section{Introduction}

Fast and flash floods in the Mediterranean area are well known for their importance and violence. They are characterised by intensive reactions by rivers, with specific discharges sometimes reaching more than $20 \mathrm{~m}^{3} \mathrm{~s}^{-1} \mathrm{~km}^{-2}$, and water rising very rapidly, generally in a few hours. These reactions are the consequence of extreme rainfall events; this cumulated rainfall can reach values exceeding $500 \mathrm{~mm}$ in $24 \mathrm{~h}$, sometimes exceeding $100 \mathrm{~mm} \mathrm{~h}^{-1}$ intensities. In France, the southeastern regions are frequently affected. The last major events were the ones that affected the River Aude in November 1999 (Gaume et al., 2004), the Gard area in September 2002 (Delrieu et al., 2005), and the Var area in June 2010 (Martin, 2010). Each of these events took many human lives, and generated damages of between 500 million and more than one billion euros.

The literature informs a set of satisfactory solutions for the flood modelling of Mediterranean rivers, at the scale of small- or medium-sized catchments (lower than some hundred $\mathrm{km}^{2}$ ). Numerous adapted hydrologic models were proposed, but there is not, at the moment, a clear consensus as to a preferential approach (Hapuarachchi et al., 2011). TOPMODEL and its derivatives (Saulnier and Le Lay, 2009; Vincendon et al., 2010), or else the models based on the SCS 
theory (see, for example, Bouvier et al., 2004; Gaume et al., 2004; Sangati and Borga, 2009), are among some of the best known.

A priori, these hydrologic models are not well adapted for the modelling of discharges in the intermediary downstream part of large Mediterranean streams draining surfaces of around $1000 \mathrm{~km}^{2}$ or more. They are based on simplified routing models (such as lag and route, unit hydrograph, etc.), which do not take into account effects due to overflowing in the floodplain, backwater effects at confluences, and impacts of hydraulic structures such as weirs and bridges (Lian et al., 2007; Mejia et Reed, 2011). In the upstream parts, these phenomena and structures often remain limited, and the hydrologic model is satisfactory. By contrast, they are frequent in the intermediary downstream parts, where the floodplain widens considerably, and where slopes, more moderated, are favourable to inundation. More sophisticated routing models are then recommended. They can be hydraulic models based on the Saint-Venant equations, or on simplifications of these (kinematic or diffusive waves). In addition to the modelling of the discharges, the hydraulic models allow us to model water levels and flooded areas.

This hydraulic model, applied to the intermediary downstream part of the river, must be fed. If inflows are obtained by hydrologic modelling, we can call it a hydrologic and hydraulic model coupling. Some examples of coupling have already been detailed in the literature (see, for example, Knebl et al., 2005; Whiteaker et al., 2006; Lian et al., 2007; Biancamaria et al., 2009; Bonnifait et al., 2009; Montanari et al., 2009; Mejia and Reed, 2011; Kim et al., 2012; Lerat et al., 2012). A single application concerns a catchment prone to fast floods: the study of Bonnifait et al. (2009), which proposes a coupling of the hydrologic n-TOPMODELs model to the CARIMA hydraulic model. The coupling is used to retrace the major event of September 2002, at the scale of the Gardon River catchment $\left(2040 \mathrm{~km}^{2}\right)$ in the south of France.

This study details the construction and the performances of a coupling of hydrologic and hydraulic models, also applied to the Gardon River basin. The proposed coupling is unidirectional. A 1-D hydraulic model based on the full SaintVenant equations is used in the intermediary downstream part of the River Gardon. It is fed by 50 upstream and lateral inflows. These inflows are modelled with a distributed, conceptual and event-based hydrologic model. The coupling results are analysed for seven recent events of medium importance, according to the discharge data recorded by the five hydrometric stations of the catchment.

An analysis in two phases is proposed. A first part estimates the qualities of the coupling modelling. Then, secondly, comparisons with the performances of other modelling options are carried out. These comparisons aim to bring elements of responses to the following questions:

- Is a simplified propagation model as successful as a full 1-D hydraulic model for the modelling of the discharges of the intermediary downstream part of the Gardon River?

- Is the use of the coupling justified for all events, or is a simple hydraulic model, without lateral inflows, sufficient in some cases?

- What is the impact of the qualities of the upstream entry hydrologic modelling on the hydraulic model?

The different modelling results are estimated at five stations of the catchment. The analysis concerns only the flood hydrographs. Other interesting contributions of the coupling, such as for example the modelling of the flooded areas, are not analysed in this study, but offer interesting perspectives.

This article is organised as follows. Section 2 provides a description of the Gardon catchment, the used hydrologic data, and the studied events. Section 3 describes the strategy for implementing the coupling approach, the hydrologic and hydraulic models, and the parameter adjustment. Section 4 details the coupling results and the results of the comparisons with the other modelling options. Finally, the article ends with a discussion (Sect. 5).

\section{Study area and flood events modelled}

\subsection{The Gardon catchment}

The Gardon River is a major tributary of the downstream part of the Rhône River, located in the southeast of France (Fig. 1). Its watershed area is $2040 \mathrm{~km}^{2}$ at the confluence. The source of the Gardon River is in the Cevennes, a low mountain range with a $1699 \mathrm{~m}$ peak, the Pic de Finiels. It contains two main upstream reaches, the Gardon d'Alès and the Gardon d'Anduze, and a single downstream reach. The Gardon d'Alès and the Gardon d'Anduze meet a few kilometres upstream from the village of Ners, in the intermediate part of the catchment.

The upstream and downstream parts of the Gardon River basin have very different features. In the upstream part, the river system has many branches, and a landscape with steeply sided valleys and steeply sloped hillsides. In some places, slopes are greater than $50 \%$. The bed slope of the Gardon River reaches $4 \%$. From a geological point of view, this area is essentially made up of former grounds of primary age, with a preponderance of schist and granites, and a lower proportion of sandstone. The vegetation consists of oak and chestnut trees, with a great number of conifers at high altitude. Downstream from Alès and Anduze, the valleys widen and create alluvial plains with deposits from the Quaternary, which in some places extend over several kilometres. The widest point is in the Gardonnenque plain (around $5 \mathrm{~km}$ ). The river system is simplified, because it crosses softer formations of the secondary era (limestone, marls, and sandstone). The bed slope is on average $0.15 \%$. Some elements of relief remain, which rarely exceed $200 \mathrm{~m}$. The landscape 


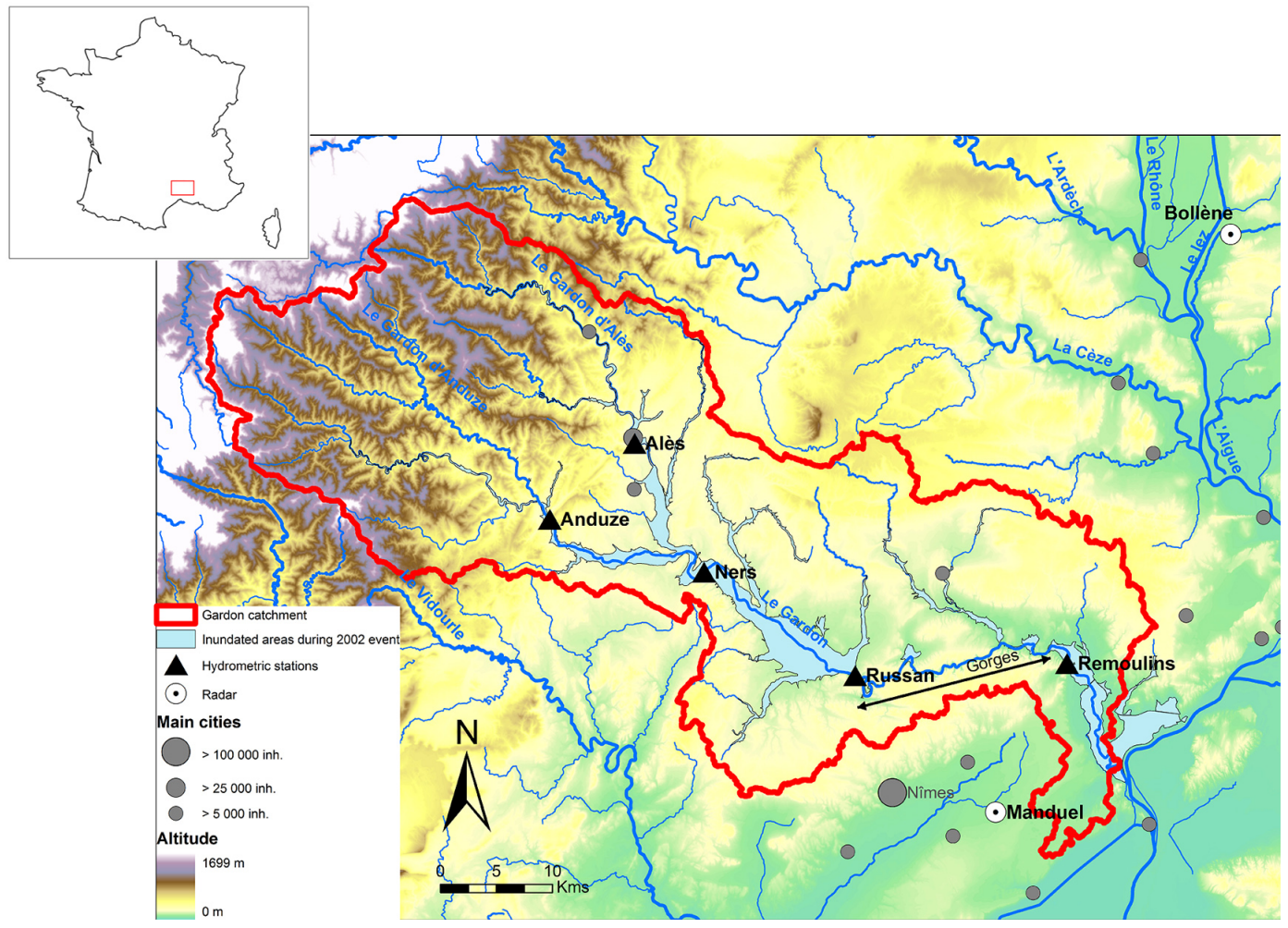

Figure 1. The Gardon catchment.

is dominated by scrubland and cropland. This zone of plains ends with the Gardon gorges, which are profoundly dug in limestone, and in some places rise up to about $100 \mathrm{~m}$. The Gardon gorges stretch over about $20 \mathrm{~km}$. The River Gardon's tributaries have a highly karstic nature in these places. Downstream from the gorges, the River Gardon crosses a zone of alluvial deposits from the River Rhône. The floodplain widens, although less so than in the Gardonnenque plain.

There are some moderately sized cities (Fig. 1) in this catchment, which is predominantly rural. Located in the intermediate part of the catchment, Alès is the biggest city, with a current population of slightly more than 40000 inhabitants. The total population in the catchment was estimated to be 191000 inhabitants in 2006 (orig.cg-gard.fr), of which about $25 \%$ live in flood-risk areas.

The climate in the Gardon watershed is typically Mediterranean. It is characterised by sometimes very intense and violent rainy events, which generally occur in the autumn. These events cause fast floods (flash floods in the upstream parts), which sometimes have tragic consequences. The catastrophic event in September 2002, which affected the River Gardon and the nearby Cèze and Vidourle river basins, is still in everyone's memory. Values cited in the literature demonstrate how exceptional it was (Delrieu et al., 2005). Cumulated rainfall of between 600 and $700 \mathrm{~mm}$ in $24 \mathrm{~h}$ was observed in the triangle linking the cities of Alès, Anduze, and Ners, which is the current record in the region. Peak specific discharges higher than $20 \mathrm{~m}^{3} \mathrm{~s}^{-1} \mathrm{~km}^{-2}$ were recorded in certain sub-catchments (Delrieu et al., 2005). There were 23 victims, and damage was estimated to be 1.2 billion euros for the whole area (Sauvagnargues-Lesage and Simonet, 2004; Ruin et al., 2008).

\subsection{Hydrological data and events studied}

Discharge data from five hydrometric stations in the catchment were used. Figure 1 indicates the locations of these stations. Table 1 provides data on the surface area drained and the catchment outlet distances for each station. Rainfall radar images at $1 \mathrm{~km}$ resolution were also analysed. They come from two Météo-France radars, located near the catchment, in the cities of Bollène and Manduel (Fig. 1). The radar images were corrected beforehand according to the rain gauge network measurements, using CALAMAR ${ }^{\circledR}$ software (Ayral et al., 2005; Thierion et al., 2011). These discharge and rainfall data were supplied by the SPC-GD (Service de Prévision des Crues Grand Delta) regional flood warning service, and have a $5 \mathrm{~min}$ time step. This fine time step is used for modelling, as it is well adapted to the fast kinetics of events in this catchment.

For this study, seven events were analysed which occurred between 2005 and 2011. These events were among the most important ones during the period for which hydrological data are the most complete. Table 2 summarises some of their 

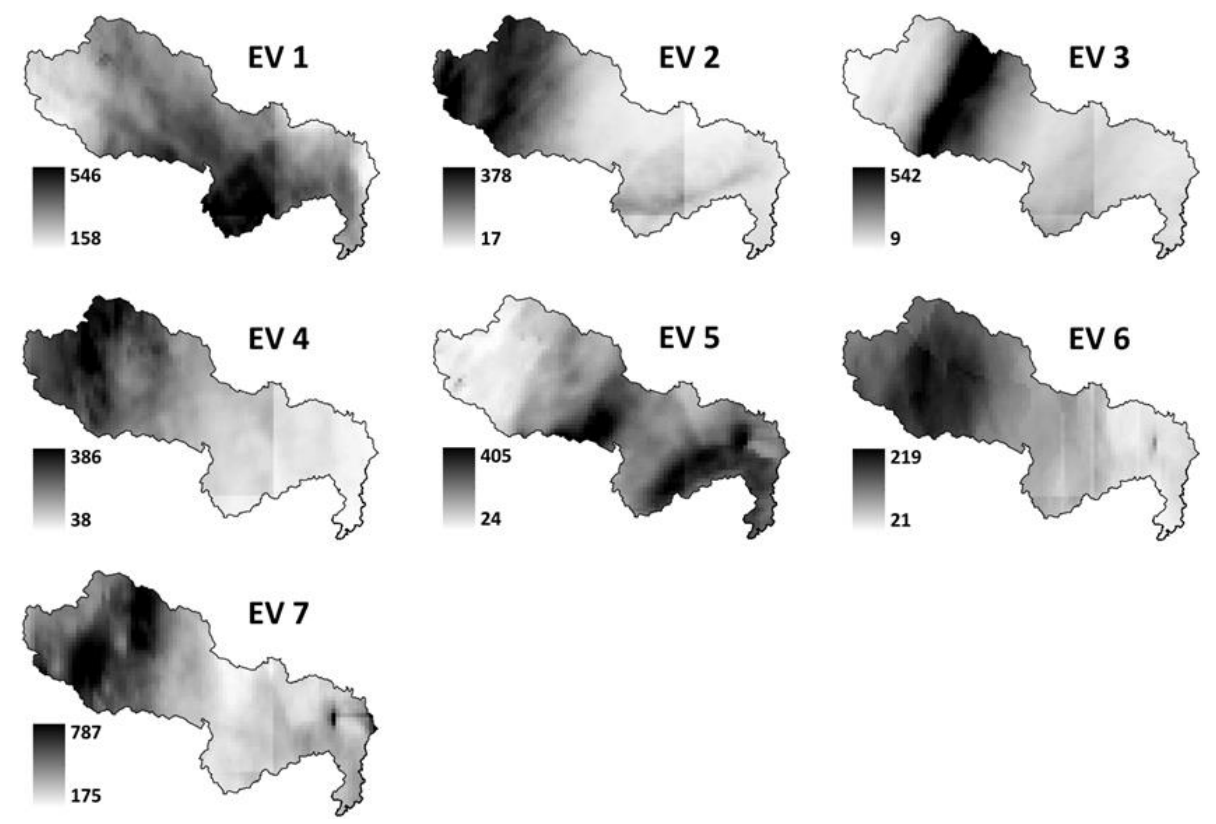

Figure 2. Cumulated rainfall $(\mathrm{mm})$ for each event.

Table 1. Drained areas and outlet distances for the five stations.

\begin{tabular}{lrc}
\hline Stations & $\begin{array}{r}\text { Drained } \\
\text { areas } \\
\left(\mathrm{km}^{2}\right)\end{array}$ & $\begin{array}{c}\text { Outlet } \\
\text { distances } \\
(\mathrm{km})\end{array}$ \\
\hline Anduze & 545 & 83.7 \\
Alès & 315 & 81.7 \\
Ners & 1100 & 64.3 \\
Russan & 1530 & 45.3 \\
Remoulins & 1900 & 13.9 \\
\hline
\end{tabular}

characteristics. Total rainfall upstream to Russan varied between $130 \mathrm{~mm}$ for event no. 6 and $370 \mathrm{~mm}$ for event no. 7 . Peak flows at this station were between $700 \mathrm{~m}^{3} \mathrm{~s}^{-1}$ (event no. 5) and $1420 \mathrm{~m}^{3} \mathrm{~s}^{-1}$ (event no. 4). Figure 2 provides data for the cumulated rainfall distribution in the catchment for each event. Two general trends can be seen:

- For event nos. 1 and 5, cumulated rainfall is more significant in the intermediary downstream part of the catchment. Table 2 shows for these two cases an increase in the volume at the downstream stations, indicating the proportionally important contribution of lateral inflows in these zones.

- For event nos. 2, 3, 4, 6, and 7, cumulated rainfall was more important in the upstream part of the catchment. This distribution of rain is the one most frequently observed (Jacq, 1994), because the Cevennes mountains amplify the rainfall. The volume increased between the upstream stations and the station of Ners, in a way, however, rather different according to the event. Lateral inflows were the most important for event nos. 6 and 7. Volumes diminished between Ners and Russan for event nos. 2, 3, and 4. This decrease can be understood in terms of karstic losses on the river bed, and/or rating curve inaccuracies. It also corresponds to insignificant contributions of lateral inflows between both stations.

Some remarks concerning the hydrological data of these events must be made. Hydrographs at the Alès station are not available for event nos. 1 and 2, because the station rating curve is not valid for these periods. The rating curve at Remoulins is very uncertain, and its discharge data were not used in this study. Finally, in the case of event no. 6, rainfall radar data are missing at the beginning of the event. They were completed by rain gauge measurements using inverse distance interpolation techniques.

\section{The coupling of models: choices and definitions}

In this part, we present the chosen coupling approach, and the models we used. Then, the application of the coupling to the Gardon River catchment is detailed.

\subsection{The choice of the type of coupling}

Two major strategies of hydrologic and hydraulic model coupling are proposed in the literature (Lian et al., 2007; Lerat, 2009; Mejia and Reed, 2011): unidirectional (also called external) coupling and bidirectional coupling (internal coupling). In the first case, the information is exchanged in one direction only, from the hydrologic model to the hydraulic 
Table 2. Some key event characteristics. AN, N, and RU stand for the Anduze, Ners, and Russan stations. UP groups together both upstream sub-catchments (Anduze and Alès). The rating curve at the Alès station having been achieved after event nos. 1 and 2 , volumes were not calculated in these two cases.

\begin{tabular}{|c|c|c|c|c|c|c|c|c|c|c|}
\hline \multirow[t]{2}{*}{ Event } & \multirow[t]{2}{*}{ Period } & \multicolumn{3}{|c|}{ Mean rainfall $(\mathrm{mm})$} & \multicolumn{3}{|c|}{ Runoff volume $\left(\mathrm{M} \mathrm{m}^{3}\right)$} & \multicolumn{3}{|c|}{ Peak discharge $\left(\mathrm{m}^{3} \mathrm{~s}^{-1}\right)$} \\
\hline & & UP & $\mathrm{N}$ & RU & UP & $\mathrm{N}$ & $\mathrm{RU}$ & $\mathrm{AN}$ & $\mathrm{N}$ & $\mathrm{RU}$ \\
\hline 1 & 5-12 Sep 2005 & 280 & 300 & 320 & - & 63 & 99 & 150 & 460 & 850 \\
\hline 2 & $18-22$ Oct 2006 & 210 & 170 & 140 & - & 91 & 85 & 1300 & 1340 & 1290 \\
\hline 3 & 21-24 Oct 2008 & 190 & 180 & 160 & 46 & 52 & 50 & 1070 & 1390 & 1340 \\
\hline 4 & 1-4 Nov 2008 & 250 & 230 & 190 & 98 & 118 & 113 & 1040 & 1290 & 1420 \\
\hline 5 & 6-9 Sep 2010 & 90 & 120 & 140 & 2 & 15 & 21 & 20 & 560 & 700 \\
\hline 6 & 21-28 Dec 2010 & 160 & 150 & 130 & 97 & 126 & 133 & 360 & 730 & 880 \\
\hline 7 & 2-09 Nov 2011 & 460 & 430 & 370 & 195 & 222 & 229 & 1070 & 1120 & 1300 \\
\hline
\end{tabular}

model. Hydrographs obtained with the hydrologic model feed the hydraulic model, which is used at a second stage. It is the simplest strategy of coupling, and the most frequently used (Lerat, 2009). For the bidirectional coupling, the hydraulic model interacts with the hydrologic model, allowing more realistic modelling at confluences (backwater effects are taken into account). At each time step of the modelling, both models are made consistent, according to a complex procedure. An example of this approach to coupling is detailed by Kim et al. (2012).

In this study, an external coupling of models was chosen. Several criteria motivate this choice. Firstly, this type of coupling is more flexible: the models can be easily changed, if it is needed (Whiteaker et al., 2006). This fact is important, because there is still no clear consensus on a preferred approach to hydrologic modelling of flash floods, as stated by Hapuarachchi et al. (2011). Thus, if a more relevant hydrologic model is developed in the coming years, it can be easily integrated into the coupling, simply by replacing the former model. Furthermore, the implementation of a bidirectional coupling on the scale of a catchment like the Gardon River appears to be complicated, and not well adapted to the operational use expected of the tool. According to Lerat (2009), the applications of bidirectional coupling are limited to watersheds of restricted areas of a few to dozens of $\mathrm{km}^{2}$, because of the numerical complexity of the approach. The durations of modelling, and numerical instabilities, are more important for a bidirectional coupling than for a unidirectional coupling.

\subsection{The choice of the models}

The external coupling combines a hydrologic model and a hydraulic model. In this section, the choice of both models is detailed.

As indicated in the introduction, the coupling must be able to estimate discharges, water levels, and flooded areas at every point of the stream. This spatially distributed information would be of a particular interest for flood forecasting. Thus, the used coupling has to contain a hydraulic model based on the Saint-Venant equations, or on simplified approximations of these equations. Propagation models, such as the Muskingum (McCarthy, 1938) or lag and route (Linsley et al., 1949) models, are dismissed, because they do not allow the estimation of the flooded areas. However, discretised versions of these two approaches, as for example the Muskingum-Cunge model (Miller and Cunge, 1975), would be, a priori, a satisfying approach for the modelling of discharges at each point of the reach.

This first choice made, the question of the dimension and the simplification level of the equations of the hydraulic model is asked. The hydraulic models can be in one, two, or three dimensions. The 3-D models are rather infrequent in the literature, and their field of application is restricted to very short reaches, lower than one kilometre. At the complete scale of a stream, 1-D or 2-D models are used. The 1-D models constitute the oldest approach, but are still in wide use and development (Horritt and Bates, 2002; Cook and Merwade, 2009). They can be completed by storage areas for a finer representation of overflow. The 2-D models are more realistic, being released from the constraint of axial flow. They present, as main weak points, a heavy implementation requiring a large number of data (fine topography, local roughness, etc.), as well as extended calculation times, which limit even at present their interest for operational use. Thus, we favour a 1-D hydraulic model.

It can be based on the full Saint-Venant equations, or on simplifications of these ones: the kinematic wave and the diffusive wave. According to Kampf and Burges (2007), the use of the kinematic wave is valid for streams with steep slopes (higher than $0.2 \%$ ), and when lateral inflows stay moderate. The River Gardon, with bed slopes around $0.1 \%$ in its downstream part, and with lateral inflows which can be important, seems poorly adapted to this option. The hypothesis of the diffusive wave, less restrictive, is a priori more satisfactory. Moussa and Bocquillon (2009) apply a model based on this approximation to the Lez River catchment, neighbouring the Gardon River basin, and obtain good results. A hydraulic model based on the full Saint-Venant equations requires fine 
topographic data, and its calculation times are more important. These calculation times remain interesting for an operational purpose (of a few minutes). Thus, a 1-D hydraulic model based on the full Saint-Venant equations, or on the simplification of the diffusive wave, seems to be adapted to the context of the study. We choose a 1-D hydraulic model based on the Saint-Venant equations.

This hydraulic model is fed by hydrologic modelling of lateral and upstream inflows. To satisfy the operational issue, a hydrologic model containing a few parameters, with short calculation times, is favoured. Also, it must be adapted to the context of floods of Mediterranean catchments. Particularly, studies of Mediterranean basins showed clear improvements in modelling when spatially distributed rainfall data are used at the entrance of the hydrologic model (Saulnier and Le Lay, 2009; Sangati and Borga, 2009; Sangati et al., 2009; Anquetin et al., 2010; Zoccatelli et al., 2010; Tramblay et al., 2011). Thus, we choose a conceptual and distributed model based on a simplified but physically based description of the catchment.

The coupling uses the SCS-LR hydrologic model implemented in the ATHYS modelling platform (http://www. athys-soft.org), and the MASCARET 1-D hydraulic modelling code, based on full Saint-Venant equations. The ATHYS platform is developed by the IRD (Institute of Research for Development), and the MASCARET code by EDF (Electricité De France - French electric company) and the CETMEF (Centre d'Etudes Techniques Maritimes et Fluviales). Both tools, which will be described in the following section, are open source.

\subsection{Description of the models}

\subsubsection{SCS-LR hydrologic model}

The SCS-LR model combines a runoff model adapted from the Soil Conservation Service (SCS) and a lag-and-route (LR) model based on a cascade of linear reservoirs. It is an event-based, distributed, conceptual model with reservoirs, based on a discretisation of the catchment in regular square cells. It has been used in many studies of Mediterranean watersheds of a limited area, in particular concerning the Gardon d'Anduze River basin (Bouvier et al., 2004, 2006; Marchandise, 2007; Marchandise and Viel, 2009; Coustau, 2011; Tramblay et al., 2011). It proves to be successful for modelling typical floods in Mediterranean watersheds, particularly compared with other models (Bouvier et al., 2006; Marchandise, 2007; Coustau, 2011).

The SCS runoff model associates a time variable runoff coefficient $C(t)$ with every grid cell, which depends on the cumulated rainfall $P(t)$, and on an $S$ parameter characterising the initial water deficit in the catchment area:
$C(t)=\left(\frac{P(t)-0.2 S}{P(t)+0.8 S}\right)\left(2-\frac{P(t)-0.2 S}{P(t)+0.8 S}\right)$,

with $P(t)$ and $S$ in mm, $C(t)$ in $\%$.

This runoff coefficient increases with the cumulated rainfall. To represent its decrease during periods without rains, a reduction of $P(t)$ is added:

$\frac{\mathrm{d} P(t)}{\mathrm{d} t}=P b(t)-\mathrm{d} s P(t)$,

where $P b(t)$ is the instantaneous precipitation in $\mathrm{mm} \mathrm{h}^{-1}$, and $\mathrm{d} s$ a draining coefficient $\left(\mathrm{h}^{-1}\right)$.

Finally, the runoff $R(t)$ of the cell $\left(\mathrm{mm} \mathrm{h}^{-1}\right)$ is expressed as

$R(t)=C(t) P b(t)$.

The LR routing model is based on the definition of a propagation time $T_{m}$ and a diffusion time $K_{m}$ for each cell $m$, estimated from the cell-to-outlet distances $l_{m}$ :

$\begin{aligned} T_{m} & =\frac{l_{m}}{V_{0}}, \\ K_{m} & =K_{0} T_{m},\end{aligned}$

where $V_{0}$ is the speed of propagation $\left(\mathrm{m} \mathrm{s}^{-1}\right)$, and $K_{0}$ a coefficient without dimension. The elementary discharge $q(t)$ at the outlet, corresponding to the propagation of the runoff $R\left(t_{0}\right)$ generated at the cell $m$ at time $t_{0}$, is

$q(t)=0$ if $t<t_{0}+T_{m}$,

$q(t)=\frac{r(\Delta t)}{K_{m}} \exp \left(-\frac{t-\left(t_{0}+T_{m}\right)}{K_{m}}\right) B$ if $t>t_{0}+T_{m}$,

where $r(\Delta t)$ is the runoff modelled at the cell $m$ between times $t_{0}$ and $t_{0}+\Delta t(\mathrm{~mm})$, with $\Delta t$ the time step of the modelling (min) and $B$ the cell surface.

Finally, the complete flood hydrograph is obtained by adding all the contributions of the cells, at each time. A fiveminute time step is used for modelling.

This model is a simplified version of the complete SCSLR model of the ATHYS platform, and is identical to the one used by Tramblay et al. (2011). In this version, the contribution of soil drainage to delayed flows is ignored. Tramblay et al. (2011) showed that it gives satisfactory results for 16 events at the Anduze station. In addition to this last observation, this version was chosen because it has a low number of adjustment parameters, which is an important criterion for flood forecasting. The model contains four parameters for which values must be defined: $S, \mathrm{~d} s, V_{0}$ and $K_{0}$. The adjustment is detailed in Sect. 3.6.

\subsubsection{The MASCARET hydraulic model}

MASCARET is the 1-D hydraulic modelling code used for developing the hydraulic model. It can be used to calculate 


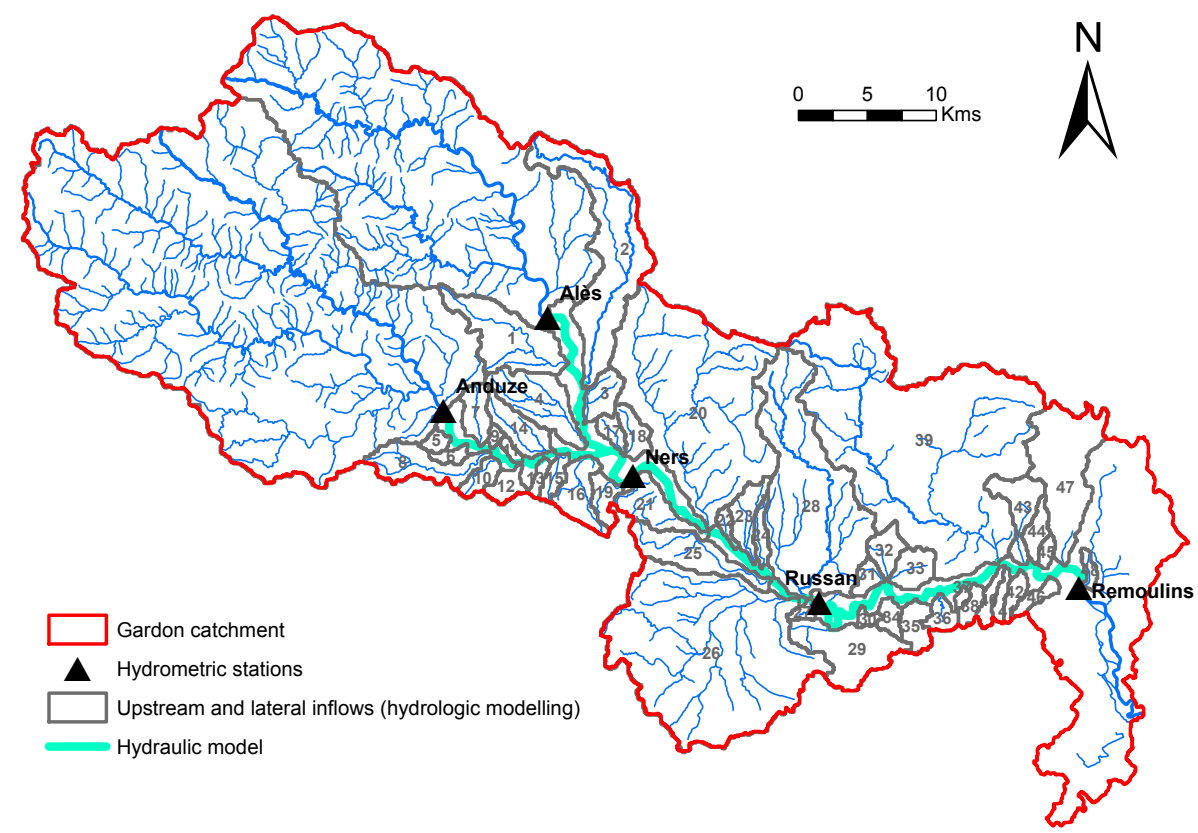

Figure 3. Coupling of models applied to the Gardon River basin.

steady and unsteady flows in fluvial and transcritical systems. It is based on full Saint-Venant equations, composed of the continuity equation

$\frac{\partial Q}{\partial x}+\frac{\partial A}{\partial t}=q_{1}$

and the dynamic equation

$$
\frac{\partial Q}{\partial t}+\frac{\partial}{\partial x}\left(\beta \frac{Q^{2}}{A}\right)+g A\left(\frac{\partial y}{\partial x}\right)+g A\left(S_{\mathrm{f}}-S_{0}\right)=0,
$$

where $Q$ is the discharge $\left(\mathrm{m}^{3} \mathrm{~s}^{-1}\right), x$ the longitudinal distance $(\mathrm{m}), A$ the wetted area $\left(\mathrm{m}^{2}\right), q_{1}$ the lateral inflows by metre $\left(\mathrm{m}^{2} \mathrm{~s}^{-1}\right), \beta$ the Boussinesq coefficient, without dimension, characterising the variations of speed in the cross section, $g$ the gravity $\left(\mathrm{m} \mathrm{s}^{2}\right), y$ the water depth $(\mathrm{m}), S_{\mathrm{f}}$ the friction slope $\left(\mathrm{m} \mathrm{m}^{-1}\right)$, and $S_{0}$ the bed slope $\left(\mathrm{m} \mathrm{m}^{-1}\right)$. Using the Manning-Strickler expression, $S_{\mathrm{f}}$ can be written as

$S_{\mathrm{f}}=\frac{Q^{2}}{K_{\mathrm{s}}^{2} A^{2} R_{\mathrm{h}}^{4 / 3}}$,

with $K_{\mathrm{S}}$ the Strickler coefficient $\left(\mathrm{m}^{1 / 3} \mathrm{~s}^{-1}\right)$ which characterises flow resistance, and $R_{\mathrm{h}}$ the hydraulic mean radius (m) such as $R_{\mathrm{h}}=A / P$, with $P$ the wetted perimeter (m).

The 1-D Saint-Venant models are subjected to several hypotheses:

- the flow follows a privileged direction;

- the density of water is supposed constant;
- the pressure is distributed in a hydrostatic way;

- the slope of the stream is moderated (lower than 10\%).

The 1-D Saint-Venant equations are based on a discretisation of topography in cross sections (Samuels, 1990). In the face of hydraulic structures (weirs, dams, etc.), they are replaced locally by adapted hydraulic equations. Some examples are given in EDF-CETMEF (2011). Numerical techniques are used to solve the equations. Two schemes, explicit and implicit, are implemented in the MASCARET code, and are at the user's choice.

The model has several adjustment parameters: the $K_{\mathrm{s}}$ Strickler coefficient $\left(\mathrm{m}^{1 / 3} \mathrm{~s}^{-1}\right)$, the values of friction losses, and the coefficients of the hydraulic structure equations.

\subsection{Application of the coupling to the Gardon River basin}

Figure 3 shows how the coupling of models was implemented in the studied catchment. The MASCARET hydraulic model is applied from the Anduze and Alès stations up to the Remoulins station. Floodplains widen considerably downstream from both stations, leading to important overflowing during strong floods, which justify the employment of a hydraulic model. The studied reach includes the gorges zone, which is very influential during extreme events, in particular during the one of September 2002 (see Fig. 1).

The hydraulic model consists of three reaches. Both upstream reaches correspond to the downstream parts of the Gardon d'Anduze and Gardon d'Alès, which are 14.5 and $12.5 \mathrm{~km}$ long. The downstream reach connects the confluence with the Remoulins station, and is $55.2 \mathrm{~km}$ long. The 
total extent of the hydraulic model is $82.2 \mathrm{~km}$. There are about 50 inflows, with two major upstream inflows (the Alès and Anduze sub-catchments) and 48 lateral inflows (Fig. 3). Lateral inflows were defined on the basis of a minimum threshold area of $1 \mathrm{~km}^{2}$. The average area of lateral subcatchments is $20 \mathrm{~km}^{2}$, for a median value of $5 \mathrm{~km}^{2}$. Subcatchment nos. 2, 20, 26, 28, and 39 have areas greater than $50 \mathrm{~km}^{2}$, the maximum being $203 \mathrm{~km}^{2}$ for inflow no. 39. All in all, the selected lateral sub-catchments cover $92 \%$ of the area between both upstream stations and the Remoulins station.

\subsection{Model characteristics}

The 50 lateral inflows are modelled with the SCS-LR model, in a simplified version (see Sect. 3.3.1). The cell grid of the model is built from a digital elevation model (DEM) of the IGN's BD ALTT ${ }^{\circledR}$ (Institut national de l'information géographique et forestière). The cell size is $100 \times 100 \mathrm{~m}$. This resolution is particularly well adapted to the smallest lateral sub-catchments. The flow paths between each cell, allowing the cell to outlet distances $\left(l_{m}\right)$ to be evaluated, were forced according to the river polylines of the IGN's BD CARTHAGE $^{\circledR}$.

The rainfall data at the entrance of the model are the CALAMAR ${ }^{\circledR}$ data at $1 \mathrm{~km}$ resolution, evoked in Sect. 2.2. For a given cell of the model, the rainfall data in input is the one of the CALAMAR ${ }^{\circledR}$ pixel which overlaps the cell.

As indicated above, the hydraulic model contains three main reaches (Fig. 3) connected by a zone of confluence. The topographic data at the entrance of the hydraulic model are cross sections. They are identical to those of the study of Bonnifait et al. (2009). They had been collected with the SPC-GD and with the SMAGE (Syndicat Mixte d'Aménagement des Gardons). Missing in the gorges sector, the authors had to complete them by means of $1: 25000$ maps. All in all, the hydraulic model used contains 161 cross sections. To limit miscalculations, additional sections were interpolated. The spacing of cross sections varies from 10 to $50 \mathrm{~m}$, depending on zones.

Bridges and weirs of the Gardon River were taken into account in the model. The geometries of the bridges which were recovered, were integrated into cross sections. Coefficients of friction losses were associated to them. Weirs are modelled by means of specific hydraulic equations (see EDFCETMEF, 2011), containing two parameters: the weirs crest elevation, and a discharge coefficient. All in all, the model contains 15 bridges and 18 weirs.

The initial condition of the hydraulic model is a water line, characterising the base flow. In this study, it is identical for all the events, and corresponds to a constant discharge of $5 \mathrm{~m}^{3} \mathrm{~s}^{-1}$ injected into both upstream stations.

The time step of SCS-LR modelling is $5 \mathrm{~min}$. In the case of the hydraulic model, the explicit resolution scheme chosen requires a very fine time step for modelling, $0.1 \mathrm{~s}$ in this case. The model outputs are then sampled at a 5 min time step.

\subsection{Model parameter adjustments}

The SCS-LR hydrologic model, as indicated previously, contains four parameters to be adjusted. An identical strategy to that adopted by Tramblay et al. (2011) is chosen: the $S$ and $V_{0}$ parameters are adjusted for each event, and the $\mathrm{d} s$ and $K_{0}$ parameters are fixed to a constant value. The model is particularly sensitive to the $S$ values. The $V_{0}$ parameter influences essentially the value and the time of arrival of the peak. Modelling of about twenty events at Anduze, carried out in parallel to this study, were sometimes improved very clearly after calibration of this parameter. It is also calibrated, after this observation. Concerning the $\mathrm{d} s$ and $K_{0}$ parameters, the values used by Tramblay et al. (2011) are used, i.e.: $\mathrm{d} s=0.4$ and $K_{0}=1.5$.

The $S$ and $V_{0}$ parameters are calibrated according to observed hydrographs at the Anduze station. For this purpose, the simplex iterative algorithm (Nelder and Mead, 1965), implemented in the ATHYS platform, is used. The algorithm is based on the maximisation of a quality criterion of the modelling. In this particular case, the Nash criterion (Nash and Sutcliffe, 1970) is used:

Nash $=1-\frac{\sum_{i=1}^{T}\left(Q_{\mathrm{OBS}, i}-Q_{\mathrm{MOD}, i}\right)^{2}}{\sum_{i=1}^{T}\left(Q_{\mathrm{OBS}, i}-\overline{Q_{\mathrm{OBS}}}\right)^{2}}$,

where $T$ is the event duration, $Q_{\mathrm{OBS}, i}$ and $Q_{\mathrm{MOD}, i}\left(\mathrm{~m}^{3} \mathrm{~s}^{-1}\right)$ are the observed and modelled discharges at time step $i$, and $\overline{Q_{\text {OBS }}}$ is the mean of the observed discharges $\left(\mathrm{m}^{3} \mathrm{~s}^{-1}\right)$.

The calibration domain only includes discharges higher than $50 \mathrm{~m}^{3} \mathrm{~s}^{-1}$, to limit the influence of low values. However, in the case of event no. 5, for which peak flow does not reach this threshold at Anduze (Table 2), the calibration procedure was applied to discharges higher than $10 \mathrm{~m}^{3} \mathrm{~s}^{-1}$.

The $S$ and $V_{0}$ values obtained after calibration are then used for the modelling of the 49 other inflows (the Alès subcatchment and the 48 lateral inflows). The ds and $K_{0}$ fixed values are employed equally.

Table 3 indicates the parameter values calibrated at Anduze for the 7 events studied. The $S$ parameter values follow a coherent trend. For events arising just after the summer season, the $S$ parameter is high, characterising an important water deficit. On the contrary, for events in NovemberDecember, the values are lower, since rainy events at the beginning of autumn have contributed in a more or less significant way to refilling the catchment. The $V_{0}$ values are rather variable, but coherent with the classically observed speeds. The performance of the hydrologic modelling is described in Sect. 4.1.1.

The parameters of the hydraulic model are the Strickler coefficients $K_{\mathrm{s}}$, the friction loss coefficients, and the coefficients of the hydraulic equations associated with weirs. The friction losses were defined according to the values of 
Table 3. $S$ and $V_{0}$ parameters calibrated at the Anduze station, for the seven events studied.

\begin{tabular}{lcc}
\hline Event & $S$ & $V_{0}$ \\
\hline 1 & 391 & 1.6 \\
2 & 238 & 3.6 \\
3 & 408 & 3.1 \\
4 & 203 & 3.0 \\
5 & 367 & 1.4 \\
6 & 108 & 1.6 \\
7 & 227 & 2.7 \\
\hline
\end{tabular}

the literature (EDF-CETMEF, 2011). Both parameters of the weirs equation, i.e. the weir crest elevation and the discharge coefficient, respectively, are derived respectively from the IGN's BD TOPO ${ }^{\circledR}$ and from the literature (EDF-CETMEF, 2011).

The $K_{\mathrm{s}}$ Strickler coefficients of the hydraulic model were empirically adjusted. The procedure consisted in reducing as much as possible the time differences between the observed and simulated peaks, and between the observed and simulated beginning of flood rises, at the three stations in Ners, Russan, and Remoulins. The beginning of the flood rise is identified as the first discharge value exceeding $50 \mathrm{~m}^{3} \mathrm{~s}^{-1}$. All in all, 11 sets of Strickler coefficients are assessed. The tested values vary from 15 to 30 on the river bed, and from 10 to 15 in the floodplain. These values of Strickler coefficients seem adapted to the Gardon River: Bonnifait et al. (2009) obtain, after calibration, $K_{\mathrm{S}}$ values of 15 and of 20 in the same stream. The adjustment procedure was applied to event no. 3. The hydrographs observed at Anduze and Alès and the lateral inflows modelled are the boundary conditions of the hydraulic model. This event was chosen because the lateral inflow contributions were weak (Table 2) and had little influence in terms of shifting the peak times.

The performances of these sets of coefficients are estimated according to the average time differences at the three stations, of the peak and of the beginning of flood rises. The best set considered a Strickler coefficient of 25 in the river bed, except in the gorges, where it was 30 , and 10 in the floodplain. This parameterisation is very satisfactory in terms of peak flow timing. The peak modelled for event no. 3 was 5 min late at Ners, 5 min early at Russan, and on time at Remoulins. The peak propagation times from one station to another seem to be entirely satisfactory. Performance was a bit less satisfactory concerning the beginning of flood rise times, with an average delay of $1 \mathrm{~h}$ at the three stations. Concerning this last point, the sets considering Strickler coefficients equal to 30 in the river bed are more satisfactory. They are however less adapted for the modelling of peaks: the time difference is between approximately $30 \mathrm{~min}$ and more than $1 \mathrm{~h}$. The set of parameters considering a coefficient of 25 in the river bed, of 30 in the gorges areas, and of 10 in floodplain, is thus used for all the other events in the study.
In this way, only two parameters of the coupling ( $S$ and $\left.V_{0}\right)$ were adjusted for each event, at the Anduze station. Other parameters and initial conditions remained identical. This parsimonious criterion makes the coupling very interesting from an operational point of view.

\subsection{Performance assessment}

The performance of the coupling of models was evaluated by analysing discharge data from five stations in the catchment area, as shown in Fig. 1. The quality of the hydrologic modelling was estimated on the basis of hydrographs recorded at Anduze and Alès, and for lateral inflows, according to the differences in volume observed between two consecutive stations. The performance of the coupling was evaluated at three stations in the downstream part of the catchment (Ners, Russan, and Remoulins).

Three quality indicators were assessed. First, the Nash coefficient, which was already mentioned in the last section. It provides information on the overall quality of the hydrographs modelled. The other two indexes are specific to peak flow. These coefficients are the relative error for peak flow $\mathrm{RE}_{Q m}(\%)$, and the temporal difference between the observed and simulated peaks $\Delta T_{Q m}(\mathrm{~min})$ :

$$
\begin{aligned}
\mathrm{RE}_{Q m} & =\frac{Q m_{\mathrm{MOD}}-Q m_{\mathrm{OBS}}}{Q m_{\mathrm{OBS}}} \times 100 \\
\Delta T_{Q m} & =T m_{\mathrm{MOD}}-T m_{\mathrm{OBS}}
\end{aligned}
$$

with $Q m_{\mathrm{MOD}}$ and $Q m_{\mathrm{OBS}}$ as the modelled and observed peak flows $\left(\mathrm{m}^{3} \mathrm{~s}^{-1}\right)$, and $T m_{\mathrm{MOD}}$ and $T m_{\mathrm{OBS}}$ as the corresponding times. A positive $\mathrm{RE}_{Q m}$ value indicates an overestimation in the peak modelled, and conversely. The $\Delta T_{Q m}$ index is positive when the peak modelled is late, and negative if it is early. At the Remoulins station, only the $\Delta T_{Q m}$ index was estimated, because the rating curve was too uncertain as indicated above.

\section{Results and discussion}

This part presents and discusses the obtained results. At first, the coupling of model results are detailed (Sect. 4.1). Then, comparisons with other modelling options are analysed (Sect. 4.2).

\subsection{Coupling results}

\subsubsection{Hydrologic modelling of upstream inflows and lateral inflows}

The SCS-LR hydrologic modelling results were evaluated at both the Anduze and Alès stations, and for lateral inflows according to the differences in volume observed between the downstream stations.

Table 4 presents the modelling results at Anduze (the calibration station) and Alès. Event nos. 1 and 2 were not 


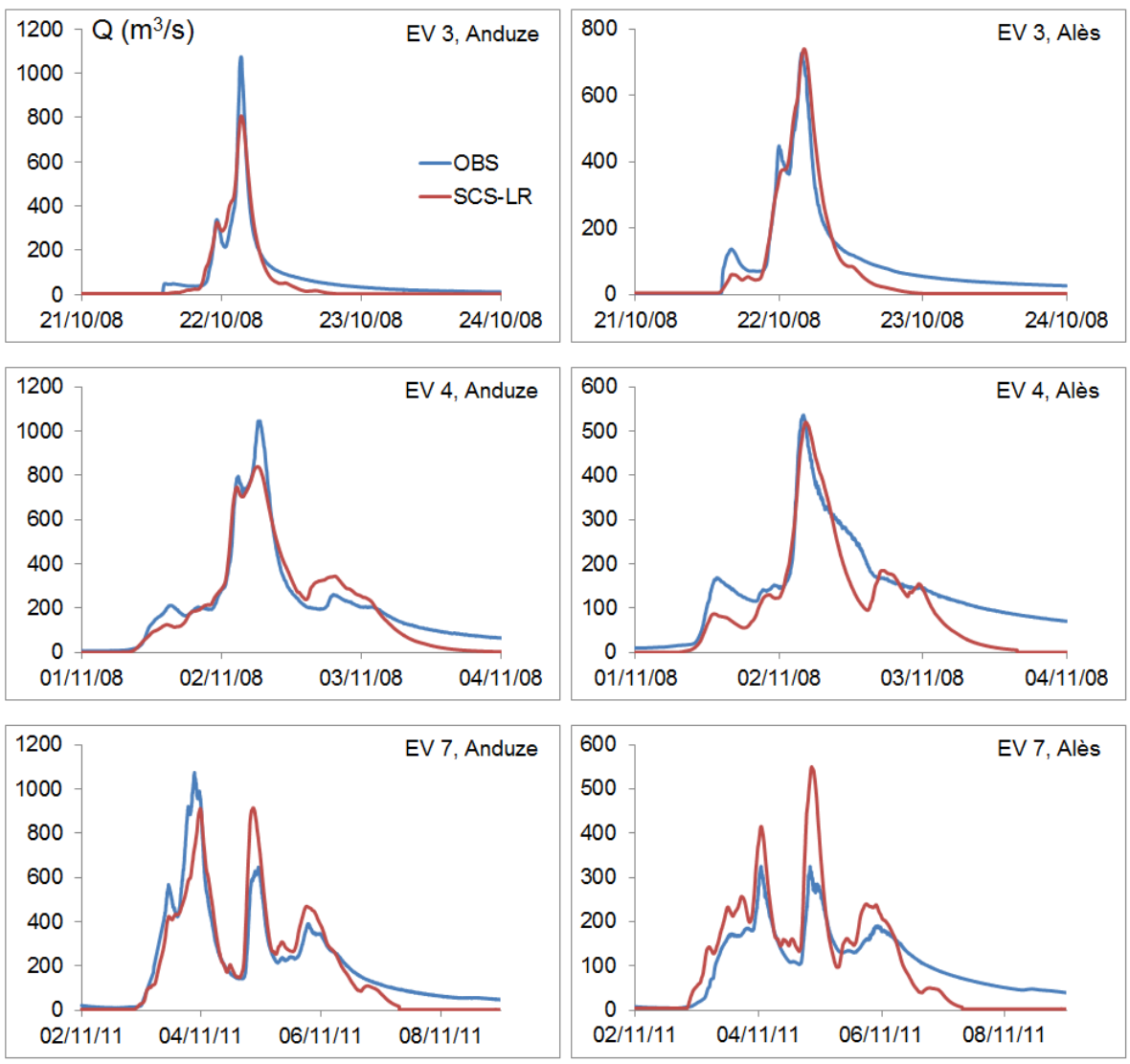

Figure 4. Hydrographs modelled with SCS-LR for event nos. 3, 4, and 7 at the Anduze and Alès stations.

Table 4. Hydrologic modelling results. Performance indexes at the Anduze and Alès stations, in terms of Nash, $\mathrm{RE}_{Q m}$ (characterising the error of the modelled peak, in \%; see Eq. 11), and $\Delta T_{Q m}$ indexes (defining the delay or the early arrival of the modelled peak, in minutes; see Eq. 12). The values of the indexes were not calculated at Alès for event nos. 1 and 2, the rating curve not being defined when these episodes arose.

\begin{tabular}{lrrrrrrr}
\hline \multirow{2}{*}{ Event } & \multicolumn{3}{c}{ Anduze } & & \multicolumn{3}{c}{ Alès } \\
\cline { 2 - 4 } \cline { 6 - 8 } & Nash & $\mathrm{RE}_{Q m}$ & $\Delta T_{Q m}$ & & Nash & $\mathrm{RE}_{Q m}$ & $\Delta T_{Q m}$ \\
\hline 1 & 0.72 & -11 & -15 & & - & - & - \\
2 & 0.87 & -10 & 10 & & - & - & - \\
3 & 0.91 & -25 & 5 & & 0.89 & 2 & 25 \\
4 & 0.90 & -20 & -5 & & 0.57 & -3 & 25 \\
5 & 0.53 & -6 & -5 & & -4.57 & 17 & 30 \\
6 & 0.68 & 15 & 705 & & -0.50 & 24 & 45 \\
7 & 0.80 & -15 & 1415 & & -0.25 & 69 & 1180 \\
\hline
\end{tabular}

provided for the second station, because the rating curve was not valid during these periods (see Sect. 2.2). Performance was generally satisfactory at Anduze, with Nash values varying from 0.53 to 0.91 . A similar range of values was observed by Tramblay et al. (2011), with the same version of the model for a 16-event set at Anduze. At the Alès station,
Nash values were very different from one event to another, indicating qualities varying from very bad to very good. The Nash index decreased for all events compared with the Anduze values. Nash values are sometimes negative, reflecting a very bad adaptation of parameters calibrated at Anduze. The peak evaluation indexes were, however, rather satisfactory at both stations. Peak error was between 0 and $\pm 25 \%$, and the $\Delta T_{Q m}$ index between 0 and $\pm 30 \mathrm{~min}$, for five events. Only event nos. 6 and 7 present major errors. These two cases contain several peaks, and a secondary peak was identified as the main peak by the model. Some hydrographs modelled at Anduze and Alès are represented in Fig. 4. Flood fall is in general rather poorly represented, particularly for winter or endof-autumn events. This observation is directly attributable to the choice of a simplified version of the SCS-LR model. In the case of event no. 7, the overestimation of the second peak could be due to an overestimation of the CALAMAR ${ }^{\circledR}$ rainfall radar data during this period of the event. Tramblay et al. (2011), being interested in several events happening in the Gardon d'Anduze basin, showed that this radar rainfall was overestimated by $23 \%$ on average with regard to the data of rain gauges.

Table 5 compares the differences in volumes observed between the downstream stations with the volumes generated 
Table 5. Comparison of the differences in volumes $\left(\mathrm{Mm}^{3}\right)$ observed between stations ( $\left.V_{\mathrm{OBS}}\right)$, and lateral inflow volumes estimated with SCS-LR ( $\left.V_{\text {SCS-LR }}\right)$, in both sections: Anduze/Alès (UP)-Ners and Ners-Russan. The $V_{\text {OBS }}$ index could not be calculated at Ners for event nos. 1 and 2, because of the lack of a rating curve during these events.

\begin{tabular}{lrrlll}
\hline \multirow{2}{*}{ Event } & \multicolumn{2}{c}{ UP-Ners } & & \multicolumn{2}{c}{ Ners-Russan } \\
\cline { 2 - 3 } \cline { 5 - 6 } & $V_{\text {OBS }}$ & $V_{\text {SCS-LR }}$ & & $V_{\text {OBS }}$ & $V_{\text {SCS-LR }}$ \\
\hline 1 & - & 15.0 & & 35.7 & 39.9 \\
2 & - & 0.2 & & 0 & 0.2 \\
3 & 5.6 & 2.4 & & 0 & 0 \\
4 & 19.4 & 5.1 & & 0 & 1.2 \\
5 & 12.9 & 9.2 & & 5.7 & 11.1 \\
6 & 28.9 & 7.5 & & 6.4 & 6.3 \\
7 & 27.7 & 18.2 & & 7.1 & 19.4 \\
\hline
\end{tabular}

by lateral inflows included between these stations, estimated with SCS-LR. The differences in volumes at Ners cannot be estimated for event nos. 1 and 2, and the hydrographs at Alès were missing, as indicated above. There appears to be a tendency to underestimate the volumes modelled for lateral inflows along the Alès/Anduze-Ners reaches, and on the contrary, a tendency to overestimate them for those along the Ners-Russan reach. There is volume compensation at the Russan station, where the total volume modelled for lateral inflows after Alès and Anduze is closer to the differences in volumes observed than at the Ners station. It is difficult to propose a physical interpretation of these inflow differences between both sections. The rather marked karstic functioning of the downstream sub-catchments, for which the hydrologic model is not in theory well adapted, the uncertainties linked to the rating curves, and a bad adaptation of parameters calibrated at Anduze, are possible explanations.

\subsubsection{Coupling performance at the downstream stations}

The results of the coupled models at the Ners, Russan, and Remoulins stations are presented in Table 6. Coefficients are generally good for the selected range of events. The Nash index is between 0.61 and 0.92 at Ners, and between 0.72 and 0.97 at Russan. Event no. 3 has the highest values at both stations, whereas event no. 2 has the lowest. The $\mathrm{RE}_{Q m}$ index has satisfactory values between 0 and $\pm 15 \%$ for most events. However, peaks for event nos. 1, 5, and 7 at the Ners station present more important errors, with the highest peak overestimation of $39 \%$ for event no. 7 . The $\Delta T_{Q m}$ index was equal to or less than $30 \mathrm{~min}$ for five events at Ners, and for four at Russan and Remoulins, which characterises good peak flow timing and confirms the hydraulic model parameterisation described in Sect. 3.6. However, this coefficient is very high at three stations for event no. 7: the delay for the peak modelled is more than $20 \mathrm{~h}$.
The results presented in Table 6 also bring to light an improvement in the Nash values at Russan, compared with those at Ners, for all events. The average increase was $13 \%$ between both stations. There is a twofold explanation for this observation. First, the improvement in the modelling of event nos. 2,3 , and 4 (varying from +0.05 to +0.11 ), for which lateral inflows at the Ners-Russan section are insignificant or of little importance (Table 5), indicates that the hydraulic model is better adapted at Russan, and/or is a more valid rating curve at this station. It is necessary to specify that the Ners station is located only $4 \mathrm{~km}$ downstream from the confluence, which complicates the hydraulic model. It is also possible that the topographic data of the hydraulic model are more precise near Russan. The second explanation concerns the other events, and particularly those for which lateral inflows are proportionally important (event nos. 1 and 5). It was previously noted that the total volume of lateral inflows from Alès and Anduze is more satisfactory at Russan than at Ners, as there is a compensation at the most downstream station. This more correct estimation also seems to be responsible for the improved results of the coupled models at Russan. The Nash values increased for event nos. 1 and 5 by +0.09 and +0.20 . If this trend toward improvement is clear for the Nash coefficient, it is barely obvious for the indexes concerning peak flow.

\subsection{Comparison with other modelling options}

The coupling of model results at the Ners, Russan and Remoulins stations is now compared with that of other modelling options. These comparisons will allow us to bring elements of responses to the following questions:

- Is a simplified propagation model as successful as a hydraulic model based on full Saint-Venant equations, for the estimation of the discharges at the Ners, Russan and Remoulins stations?

- Is the consideration of lateral inflows justified for all the events? In other words, is the choice of a coupling appropriate, or could a simple hydraulic model without lateral inflows suit?

- What is the impact of the quality of modelling injected at Anduze and Alès on the coupling results in the downstream?

For greater clarity, the COUPL MOD $_{\text {abbreviation identifies }}$ the coupling previously detailed. The following comparisons are analysed.

At first (Sect. 4.2.1), we try to estimate the influence of a simplified conceptualisation for flood wave propagations.

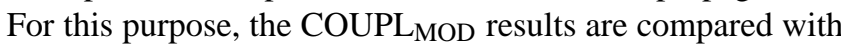
those obtained with the lag-and-route routing scheme of the SCS-LR model. This option is denoted as LR. Upstream and lateral inflows are identical in both cases. The only differences between both options concern 
Table 6. Coupling results. Performance indexes at the Ners, Russan and Remoulins stations. At Remoulins, only the $\Delta T_{Q m}$ index was calculted, the rating curve being very uncertain.

\begin{tabular}{lrrrrrrrr}
\hline \multirow{2}{*}{ Event } & \multicolumn{3}{c}{ Ners } & & \multicolumn{3}{c}{ Russan } & Remoulins \\
\cline { 2 - 3 } & Nash & $\mathrm{RE}_{Q m}$ & $\Delta T_{Q m}$ & & Nash & $\mathrm{RE}_{Q m}$ & $\Delta T_{Q m}$ & $\Delta T_{Q m}$ \\
\hline 1 & 0.77 & -23 & -30 & & 0.86 & 1 & -260 & -210 \\
2 & 0.61 & 4 & 25 & & 0.72 & -4 & 5 & 20 \\
3 & 0.92 & 3 & 15 & & 0.97 & -3 & 10 & 10 \\
4 & 0.80 & 1 & -20 & & 0.86 & -11 & -35 & -25 \\
5 & 0.68 & -30 & -15 & & 0.88 & -12 & -20 & -10 \\
6 & 0.64 & 0 & 90 & & 0.73 & -11 & 55 & 70 \\
7 & 0.75 & 39 & 1270 & & 0.79 & 15 & 1275 & 1300 \\
\hline
\end{tabular}

Table 7. LR option results. Performance indexes at the Ners, Russan and Remoulins stations. The symbols on the right of the indexes characterise the gaps compared with the COUPL MOD option. $\downarrow \downarrow$ : deterioration of more than $50 \%$; $\downarrow$ : deterioration of between 5 and $50 \%$; $\uparrow$ : improvement of between 5 and $50 \%$; $\uparrow \uparrow:$ improvement of more than $50 \%$; =: close values, within $\pm 5 \%$. Symbol also attributed to $\mathrm{RE}_{Q m}$, if the absolute difference is lower in $\pm 10 \%$, and for $\Delta T_{Q m}$, if the absolute difference is lower in $\pm 15 \mathrm{~min}$.

\begin{tabular}{llllllllll}
\hline \multirow{2}{*}{ Event } & \multicolumn{3}{c}{ Ners } & & \multicolumn{3}{c}{ Russan } & Remoulins \\
\cline { 2 - 3 } & Nash & $\mathrm{RE}_{Q m}$ & $\Delta T_{Q m}$ & & Nash & $\mathrm{RE}_{Q m}$ & $\Delta T_{Q m}$ & $\Delta T_{Q m}$ \\
\hline 1 & $0.74=$ & $-25=$ & $-50 \downarrow \downarrow$ & & $0.87=$ & $-7=$ & $-265=$ & $45 \uparrow \uparrow$ \\
2 & $0.62=$ & $-18 \downarrow \downarrow$ & $-5 \uparrow \uparrow$ & & $0.61 \downarrow$ & $-32 \downarrow \downarrow$ & $-85 \downarrow \downarrow$ & $-30=$ \\
3 & $0.93=$ & $-15 \downarrow \downarrow$ & $-30=$ & & $0.80 \downarrow$ & $-36 \downarrow \downarrow$ & $-70 \downarrow \downarrow$ & $5=$ \\
4 & $0.77=$ & $-13 \downarrow \downarrow$ & $-10=$ & & $0.73 \downarrow$ & $-32 \downarrow \downarrow$ & $-70 \downarrow \downarrow$ & $-20=$ \\
5 & $0.78 \uparrow$ & $-26=$ & $-45 \downarrow \downarrow$ & & $0.79 \downarrow$ & $-28 \downarrow \downarrow$ & $-50 \downarrow \downarrow$ & $25=$ \\
6 & $0.62=$ & $-4=$ & $15 \uparrow \uparrow$ & & $0.70=$ & $-18=$ & $-40=$ & $5 \uparrow \uparrow$ \\
7 & $0.77=$ & $22 \uparrow$ & $1280=$ & & $0.74 \downarrow$ & $-4 \uparrow \uparrow$ & $1245=$ & $1340=$ \\
\hline
\end{tabular}

- the resolute equations: full Saint-Venant equations in the case of COUPL ${ }_{M O D}$, and physically based but simplified equations in the case of the LR option (see Sect. 3.3);

- the representation of the river bed: it is very detailed in the case of COUPL in the case of LR (square cells).

Secondly, we assess the interest of adding lateral inflows (Sect. 4.2.2). The COUPL ${ }_{M O D}$ results are compared with the simple hydraulic model results, without lateral inflows. This option is noted $\mathrm{SV}_{\mathrm{MOD}}$. Upstream entries are identical for both options: they are hydrologic modelling.

Then, in the third section (Sect. 4.2.3), we try to estimate the impact of upstream entries on the hydraulic model results. For that purpose, the COUPL MOD $_{\text {results are compared }}$ with those of the coupling, integrating the observed upstream entrances. This option is denoted COUPL ${ }_{\mathrm{OBS}}$. The lateral inflows are identical for both approaches: they are SCS-LR modelling.

Finally, in the fourth part (Sect. 4.2.4), we directly estimate the importance of taking into account lateral inflows, with regard to the importance of the quality modelling for upstream inflows. The COUPL ${ }_{M O D}$ results are compared with those of the $\mathrm{SV}_{\mathrm{OBS}}$ option. This $\mathrm{SV}_{\mathrm{OBS}}$ option corresponds to the hydraulic model without lateral inflows, upstream fed by the observed hydrographs.

\subsubsection{COUPL MOD $_{\text {vs. }}$ LR: influence of a simplified routing conceptualisation}

The parameters of the LR routing model, $V_{0}$ and $K_{0}$ (see Sect. 3.3.1), are calibrated for each of seven events, on the three Alès/Anduze-Ners, Ners-Russan, and RussanRemoulins reaches, according to the hydrographs observed at downstream stations. Upstream entries and lateral inflows are identical to those of the COUPL ${ }_{M O D}$ modelling. The results of the LR option are presented in Table 7.

The Nash indexes vary according to events, between 0.62 and 0.93 at Ners, and between 0.61 and 0.87 at Russan. The $\mathrm{RE}_{Q m}$ coefficient is rather unsatisfactory at Ners, and especially at Russan: at Ners, only three events present values of the index between 0 and $\pm 15 \%$, whereas at Russan, the peak is clearly underestimated for five events (of more than $15 \%$, and until $36 \%$ for event no. 3). In the same way, the $\Delta T_{Q m}$ indexes are often important, in particular at the station of Russan, where the peak is clearly early for six events.

At the Ners station, the performances in terms of Nash are equivalent between both options, even slightly to the 


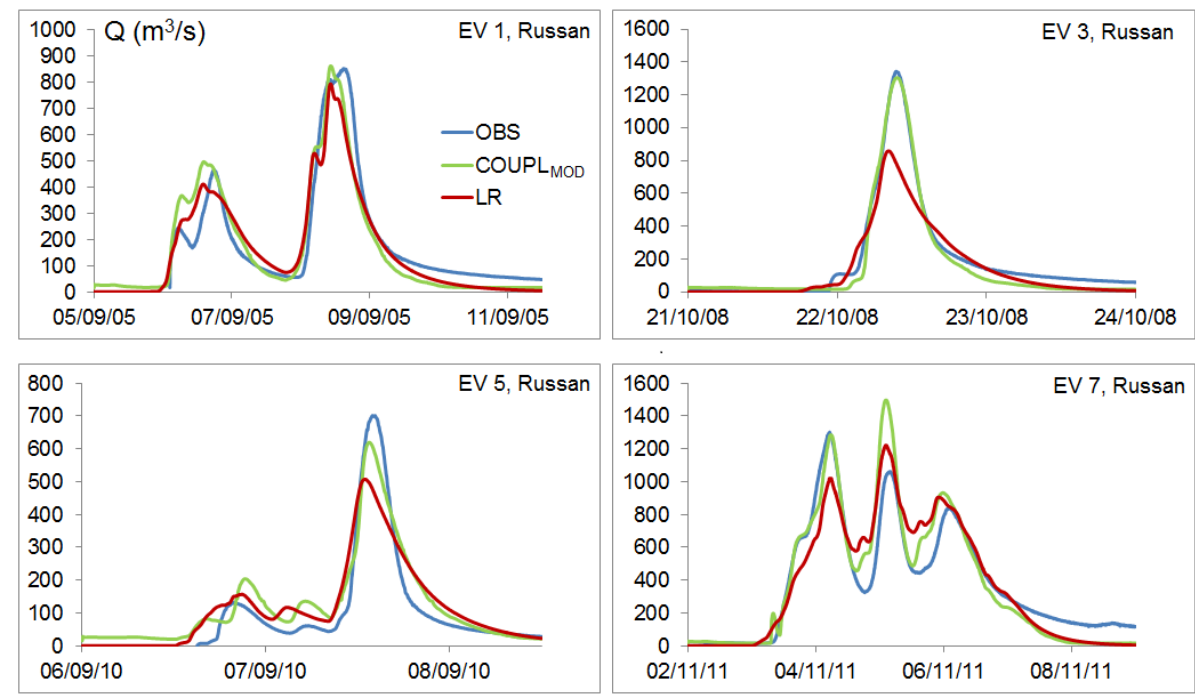

Figure 5. Hydrographs modelled for event nos. 1, 3, 5 and 7 according to the COUPL ${ }_{\text {MOD }}$ and LR modelling options, at the Russan station.

advantage of the LR option. At Russan, this option is less successful: five events present clear degradations of the Nash indexes. Concerning the $\mathrm{RE}_{Q m}$ index, consequent gaps are observed for event nos. 2, 3 and 4, at both stations. Some peaks are however reproduced in a equivalent way by both options. It is difficult to identify a global trend concerning the $\Delta T_{Q m}$ index. There are as many improvements as degradations of this index at Ners; at Russan, the COUPL MOD $_{\text {option }}$ is more successful; at Remoulins, the results are equivalent for five events, but benefit the LR option for event nos. 1 and 6.

Some hydrographs at the Russan station are detailed in Fig. 5. The performances of both options are close in the cases of event nos. 1 and 7. Concerning this last event, the Nash index is slightly degraded with the LR option ( 0.79 with COUPL MOD 0.74 with LR). The recessions between peaks, as well as the first peak, are modelled better with COUPL ${ }_{M O D}$. Concerning the remaining two events, peaks modelled with LR are rather clearly underestimated,

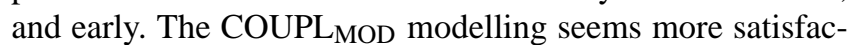
tory in these cases.

Thus, it is difficult to draw conclusions about the impact of a simplified routing conceptualisation on the downstream results. The performances of both options, COUPL ${ }_{M O D}$ and $\mathrm{LR}$, are globally equivalent at Ners; the $\Delta T_{Q m}$ indexes calculated at Remoulins are also often rather close. At Russan, it appears for four cases to be a clear degradation of modelling with the LR option (event nos. 2, 3, 4 and 5). It is maybe the location of the Russan station, just above the Gardon gorges, which explains this finding. In this sector, the river bed narrows brutally: this configuration is finely reproduced in the hydraulic model, while the LR option does not take this into account.

\subsubsection{COUPL MOD $_{\text {vs. }} \mathrm{SV}_{\mathrm{MOD}}$ : influence of adding lateral inflows}

The $\mathrm{SV}_{\mathrm{MOD}}$ option corresponds to the simple hydraulic model, without lateral inflows, fed upstream by hydrographs

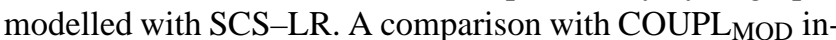
forms the interest in adding lateral inflows for the modelling. The results of the $\mathrm{SV}_{\mathrm{MOD}}$ option are indicated in Table 8.

The performances with this option are very variable according to the events. The Nash indexes are rather good for event nos. 3, 4 and 7, moderate for nos. 2 and 6, and very bad for nos. 1 and 5. In the same way, the $\operatorname{RE}_{Q m}$ and $\Delta T_{Q m}$ indexes are very bad for event nos. 1 and 5, but also for event no. 7 (except for the $\mathrm{RE}_{Q m}$ index at Russan), and, to a lesser extent however, for event no. 6 . They are rather satisfactory for the remaining three events.

The comparison with the COUPL MOD $_{\text {modelling informs }}$ significant differences according to the events. It seems these differences between both options depend on the cumulated rainfall spatial distribution (Fig. 2). The indexes obtained for event nos. 2, 3 and 4 are rather little different from those

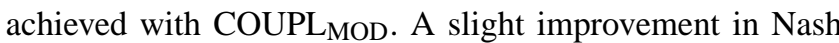
at Ners is noted in the case of event no. 4 , when the lateral inflows are added ( 0.75 vs. 0.80$)$. These three events present more significant rainfall in the upstream part of the catchment, and rather few important contributions of lateral inflows (see Table 5). This fact explains the absence of notable gaps between both options.

By contrast, for event nos. 1 and 5, and to a lesser extent for event no. 6, important differences are observed: the COUPL $L_{M O D}$ results are more satisfactory than those of $\mathrm{SV}_{\mathrm{MOD}}$, for all indexes. For example, Nash of event no. 5 evolves from -1.05 at Ners and -0.73 at Russan with the $\mathrm{SV}_{\mathrm{MOD}}$ option, to respectively 0.68 and 0.88 when lateral 
Table 8. $\mathrm{SV}_{\mathrm{MOD}}$ option results. Performance indexes at the Ners, Russan and Remoulins stations. The symbols on the right of the indexes characterise the gaps compared with the COUPL $\mathrm{MOD}_{\mathrm{M}}$ option. $\downarrow \downarrow$ : deterioration of more than $50 \%$; $\downarrow$ : deterioration of between 5 and $50 \%$; $\uparrow$ : improvement of between 5 and $50 \%$; $\uparrow \uparrow$ : improvement of more than $50 \%$; =: close values, within $\pm 5 \%$. Symbol also attributed to $\mathrm{RE}_{Q m}$, if the absolute difference is lower in $\pm 10 \%$, and for $\Delta T_{Q m}$, if the absolute difference is lower in $\pm 15 \mathrm{~min}$.

\begin{tabular}{|c|c|c|c|c|c|c|c|}
\hline \multirow[t]{2}{*}{ Event } & \multicolumn{3}{|c|}{ Ners } & \multicolumn{3}{|c|}{ Russan } & \multirow{2}{*}{$\begin{array}{l}\text { Remoulins } \\
\Delta T_{Q m}\end{array}$} \\
\hline & Nash & $\mathrm{RE}_{Q m}$ & $\Delta T_{Q m}$ & Nash & $\mathrm{RE}_{Q m}$ & $\Delta T_{Q m}$ & \\
\hline 1 & $0.14 \downarrow \downarrow$ & $-41 \downarrow \downarrow$ & $140 \downarrow \downarrow$ & $-0.10 \downarrow \downarrow$ & $-69 \downarrow \downarrow$ & $-2510 \downarrow \downarrow$ & $-2330 \downarrow \downarrow$ \\
\hline 2 & $0.61=$ & $3=$ & $25=$ & $0.72=$ & $-5=$ & $5=$ & $20=$ \\
\hline 3 & $0.92=$ & $-5=$ & $25=$ & $0.96=$ & $-11=$ & $-15=$ & $20=$ \\
\hline 4 & $0.75 \downarrow$ & $-2=$ & $-15=$ & $0.83=$ & $-14=$ & $-25=$ & $-10=$ \\
\hline 5 & $-1.05 \downarrow \downarrow$ & $-91 \downarrow \downarrow$ & $255 \downarrow \downarrow$ & $-0.73 \downarrow \downarrow$ & $-93 \downarrow \downarrow$ & $420 \downarrow \downarrow$ & $-1380 \downarrow \downarrow$ \\
\hline 6 & $0.52 \downarrow$ & $-8=$ & $135 \downarrow$ & $0.51 \downarrow$ & $-25 \downarrow \downarrow$ & $135 \downarrow \downarrow$ & $175 \downarrow \downarrow$ \\
\hline 7 & $0.81 \uparrow$ & $27 \uparrow$ & $1315=$ & $0.88 \uparrow$ & $3 \uparrow \uparrow$ & $1310=$ & $1320=$ \\
\hline
\end{tabular}
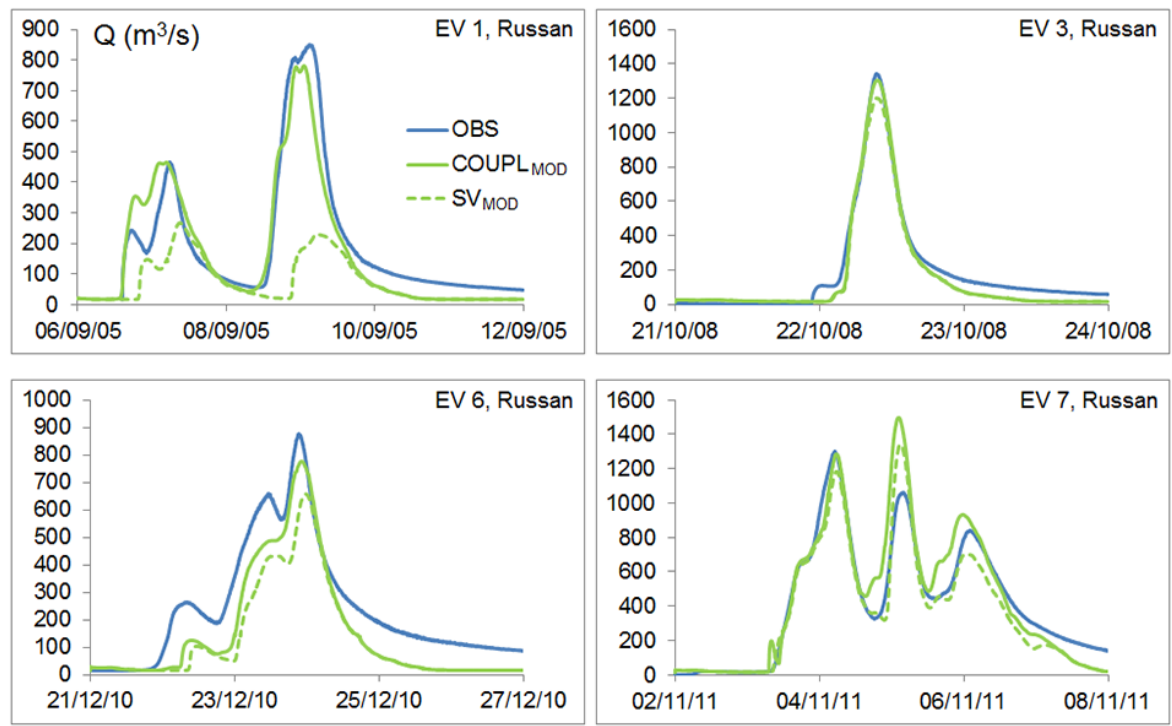

Figure 6. Hydrographs modelled for event nos. 1, 3, 6 and 7 according to the COUPL $\mathrm{MOD}_{\text {and }} \mathrm{SV}_{\mathrm{MOD}}$ modelling options, at the Russan station.

inflows are taken into account. Thus, adding these seems necessary for good modelling of these three events. Again, this finding can be explained by the rainfall spatial distribution during these events: for nos. 1 and 5, the strongest rains were measured in the intermediary downstream part of the catchment, causing very important lateral inflow responses proportional to the flows at Anduze and Alès (Tables 2 and 5); in the case of event no. 6 , the highest cumulated rainfall is observed in the upstream part of the catchment, but inflows of the intermediary downstream part react in a consequent way.

Finally, in the case of event no. 7, modelling degrades when lateral inflows are added. The Nash indexes with the $\mathrm{SV}_{\mathrm{MOD}}$ option are over +0.06 at Ners, and +0.09 at Russan. This lesser quality of the COUPLMOD results is understandable by the errors in the hydrologic model at Alès and
Anduze: the second peak of this event is rather widely overestimated at both stations (see Fig. 4). Adding lateral inflows amplifies this error in the downstream, and as a consequence, modelling is of a less good quality. This case of degradation is the only one observed when lateral inflows are added. The $\Delta T_{Q m}$ indexes remain rather close according to both options, being very bad: this is also the consequence of upstream errors.

Figure 6 details observed and modelled hydrographs with COUPL $_{\mathrm{MOD}}$ and $\mathrm{SV}_{\mathrm{MOD}}$ at Russan, for event nos. 1, 3, 6 and 7. The differences between both options are little visible in the case of event no. 3: Nash indexes are very close. How-

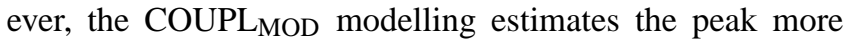
finely. Conversely, differences are very important for event no. 1. The $\mathrm{SV}_{\mathrm{MOD}}$ option underestimates the event rather widely. Flood rises are much delayed, and the second peak 
Table 9. COUPL ${ }_{\mathrm{OBS}}$ option results. Performance indexes at the Ners, Russan and Remoulins stations. The symbols on the right of the indexes characterise the gaps compared with the COUPL $\mathrm{MOD}_{\mathrm{MO}}$ option. $\downarrow \downarrow$ : deterioration of more than $50 \%$; $\downarrow$ : deterioration of between 5 and $50 \%$; $\uparrow$ : improvement of between 5 and $50 \%$; $\uparrow$ : improvement of more than $50 \%$; =: close values, within $\pm 5 \%$. Symbol also attributed to $\mathrm{RE}_{Q m}$, if the absolute difference is lower in $\pm 10 \%$, and for $\Delta T_{Q m}$, if the absolute difference is lower in $\pm 15 \mathrm{~min}$.

\begin{tabular}{|c|c|c|c|c|c|c|c|}
\hline \multirow[t]{2}{*}{ Event } & \multicolumn{3}{|c|}{ Ners } & \multicolumn{3}{|c|}{ Russan } & \multirow{2}{*}{$\begin{array}{l}\text { Remoulin } \\
\Delta T_{Q m}\end{array}$} \\
\hline & Nash & $\mathrm{RE}_{Q m}$ & $\Delta T_{Q m}$ & Nash & $\mathrm{RE}_{Q m}$ & $\Delta T_{Q m}$ & \\
\hline 1 & $0.77=$ & $-25=$ & $65 \downarrow \downarrow$ & $0.89=$ & $-9=$ & $-90=$ & $-195=$ \\
\hline 2 & $0.78 \uparrow$ & $5=$ & $20=$ & $0.85 \uparrow$ & $-6=$ & $-5=$ & $15=$ \\
\hline 3 & $0.96=$ & $9=$ & $5=$ & $0.99=$ & $-2=$ & $-5=$ & $0=$ \\
\hline 4 & $0.94 \uparrow$ & $5=$ & $30=$ & $0.97 \uparrow$ & $-8=$ & $5 \uparrow \uparrow$ & $10=$ \\
\hline 5 & $0.63 \downarrow$ & $-31=$ & $-10=$ & $0.88=$ & $-14=$ & $-20=$ & $-5=$ \\
\hline 6 & $0.95 \uparrow$ & $-13 \downarrow \downarrow$ & $5 \uparrow \uparrow$ & $0.95 \uparrow$ & $-12=$ & $-85 \downarrow \downarrow$ & $-70=$ \\
\hline 7 & $0.98 \uparrow$ & $12 \uparrow \uparrow$ & $15 \uparrow \uparrow$ & $0.95 \uparrow$ & $3 \uparrow \uparrow$ & $5 \uparrow \uparrow$ & $-50 \uparrow \uparrow$ \\
\hline
\end{tabular}

is widely underestimated. A less significant underestimation is also observed for event no. 6. Finally, in the case of event no. 7, the $\mathrm{SV}_{\mathrm{MOD}}$ option is the most satisfactory. Adding lateral inflows, overestimated on the Ners-Russan reach (see Table 5), explains the too premature increases preceding the last two peaks, and the too important values of these, in the case of the COUPL MOD $_{\text {modelling. }}$

To summarise, we can say that the interest in adding lateral inflows depends essentially on the rainfall spatial distribution of the event. However, adding lateral inflows can also contribute to the degradation of modelling, by worsening the errors in upstream entries (case of event no. 7).

\subsubsection{COUPL MOD $_{\text {vs. COUPL }}$ OBS: influence of the upstream injected hydrographs}

The COUPL $L_{\mathrm{OBS}}$ option is identical to the COUPL $\mathrm{COD}_{\mathrm{MOD}}$ option, except concerning upstream entries to the hydraulic model, which are in this case the observed hydrographs. Thus, the COUPL $_{\mathrm{OBS}} / \mathrm{COUPL}_{\mathrm{MOD}}$ comparison allows us to estimate the impact of the qualities of modelling injected at Anduze and Alès on the coupling results at the downstream. In the cases of event nos. 1 and 2, for which the rating curve at Alès is not adapted, hydrographs modelled at this station are taken into account. The results of the COUPL ${ }_{\mathrm{OBS}}$ option are indicated in Table 9.

Globally with this option, the indexes are rather satisfactory for all the events. The Nash coefficients vary between 0.63 and 0.98 at Ners, and are higher than 0.85 at Russan. The $\mathrm{RE}_{Q m}$ index is sometimes very good. Some gaps higher than $20 \%$ are however noted at Ners. Peaks are generally well synchronised. Rather important gaps are raised for some cases: event no. 1, event no. 6 at Russan and Remoulins, and event no. 7 at Remoulins. They appear to be due to hydrologic modelling errors on lateral inflows, rather than to the hydraulic model. The presented case of event no. 3 , is the case which was used to the adjustment of the $K_{\mathrm{s}}$ parameters of the hydraulic model (see Sect. 3.6).
As in the previous section, gaps in performance according to both modelling options are very different from one event to another. There are very few differences between the results of COUPL $_{M O D}$ and COUPL ${ }_{O B S}$ for event nos. 1, 3 and 5. Only the Nash indexes at Ners in the case of event no. 5, and the $\Delta T_{Q m}$ coefficients at Ners for event no. 1, present reasonable gaps. Again, the rainfall spatial distribution is an explanation of this observation. The lateral inflows were consequent during event nos. 1 and 5, minimising the importance of hydrographs injected upstream to the hydraulic model. Thus, the modelling accuracy of lateral inflows is not fundamental for these two cases. Concerning event no. 3 , it is the good modelling of hydrographs at Alès and Anduze (respective Nash indexes of 0.91 and 0.89 , see Table 4) which explains the low gap between both options at the Ners, Russan and Remoulins stations. The lateral inflows play a secondary role during this event (see Table 5).

Three other events, no. 2, 4 and 6, present clear increases of the Nash indexes, and limited differences for the $\mathrm{RE}_{Q m}$ and $\Delta T_{Q m}$ indexes when hydrographs observed upstream are injected (COUPL $L_{\mathrm{OBS}}$ option). The strongest Nash increase is observed in the case of event no. 6 at Ners (Nash of 0.64 with COUPL $_{M O D}$ vs. 0.95 with COUPL ${ }_{\mathrm{OBS}}$, an improvement of almost $50 \%$ ). This increase is explained by a better representation of flood rises and falls. For these three events, the quality of modelling at Alès and Anduze is important for the improvement in the Nash values at the downstream: this can be attributed to the strong contributions of upstream inflows, considering the flowed out volumes at the downstream stations (see Table 2). However, the two others indexes do not present clear improvements.

Finally, event no. 7 constitutes, as already observed in the previous section, a special case. All the indexes are improved with the COUPL $L_{\mathrm{OBS}}$ option. Previously observed errors of $\Delta T_{Q m}$ are widely corrected: the main peak is well identified this time.

Some modelling according to both options, at the Ners station, is presented in Fig. 7. In the case of event no. 5, the 


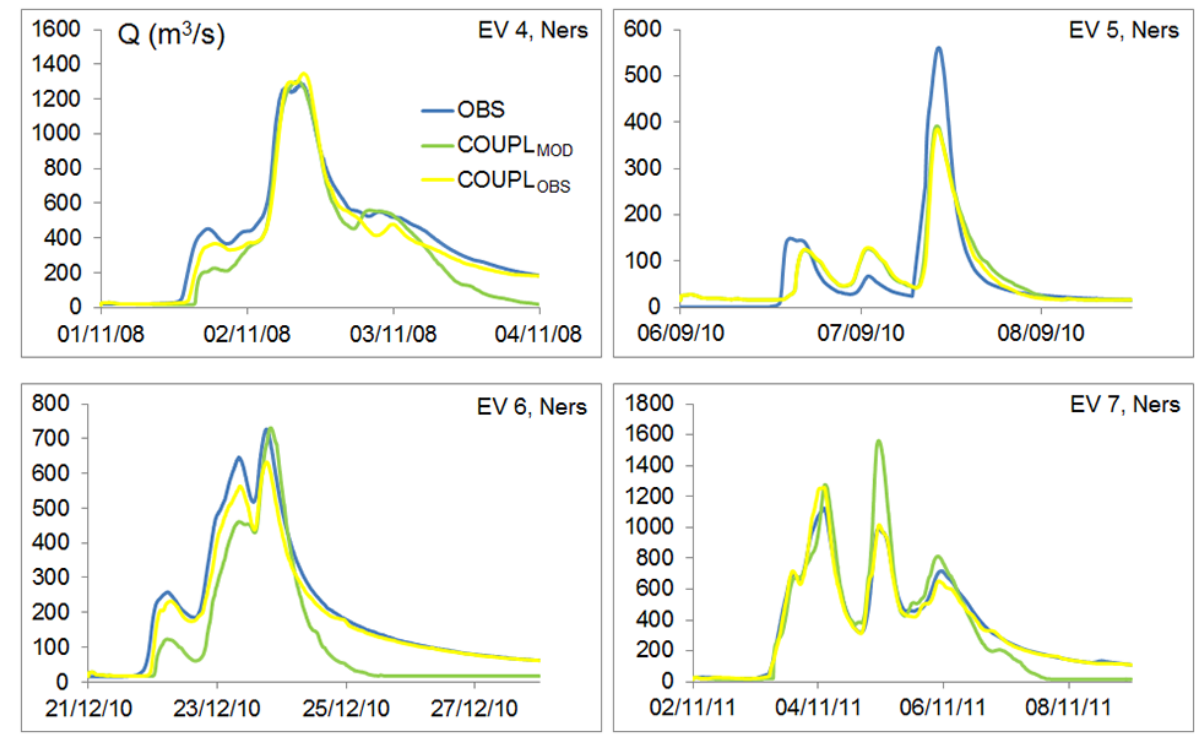

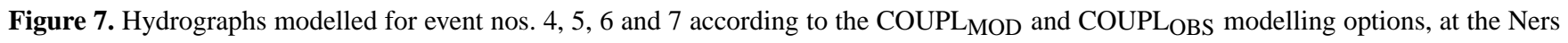
station.

results do not differ much: the quality of the modelling of upstream inflows has not got much impact. The differences are clearer concerning the other three events. In the case of event nos. 4 and 6, the flood rises and falls are better reproduced with the COUPLOBS option: modelling at Anduze and Alès underestimates them (see Fig. 4 for event no. 4). However, the peak is better reproduced with COUPL MOD $_{\text {for }}$ event no. 6: it is the combined result of overestimations of peaks at Anduze and Alès (see the $\mathrm{RE}_{Q m}$ index, Table 4) and an underestimate of the lateral inflows upstream of Ners (see Table 5), which compensates for these errors upstream. In the case of event no. 7, the improvements in the indexes are understandable by a better estimation of peaks and flood fall with the COUPL $L_{O B S}$ option. It is interesting to note the important role of both upstream catchments in flood falls, which are, except for event no. 5, far better modelled when upstream entries are the observed data.

To summarise, the results show again the important role of the rainfall spatial distribution. Events with rains essentially located in the upstream part present the most important improvements when the observed data are taken into account. However, these improvements are more debatable concerning the reconstruction of peaks: rather often, the $\mathrm{RE}_{Q m}$ and $\Delta T_{Q m}$ indexes are not very different according to both options. Only event no. 7 represents an improvement in all the indexes with COUPLOBS.

\subsubsection{COUPL COD $_{M}$ vs. $S V_{O B S}$ : direct comparison of the impact of the quality of upstream injected hydrographs vs. the importance of the lateral inflows}

In this section, the interest in adding lateral inflows is directly confronted by the impact of modelling at the upstream entries. For that purpose, the results of the hydraulic model without lateral inflows, fed by the observed data at Anduze and Alès, are compared with the COUPL MOD $_{\text {results at the }}$ three downstream stations. This modelling option is denoted $\mathrm{SV}_{\mathrm{OBS}}$, and its results are presented in Table 10.

Again, the index values, and the gaps with regard to the COUPL $_{M O D}$ modelling, are very variable according to the events. As previously mentioned, complete coupling is necessary for event nos. 1 and 5. Important gaps between both options are noted, the results of the $\mathrm{SV}_{\mathrm{OBS}}$ option being unsatisfactory. There are few differences in the case of event no. 3, for which lateral inflows are not very consistent, and SCS-LR modelling is very good at Alès and Anduze. In the case of event nos. 2, 4, 6 and 7, improvements in the Nash indexes are noticed. Concerning the other two indexes, they are equivalent for event nos. 2 and 4, clearly degraded with $\mathrm{SV}_{\mathrm{OBS}}$ for event no. 6, and improved with this same option for event no. 7. These trends appear for the modelled hydrographs presented, for some events, in Fig. 8.

For event no. 1, gaps are consequent. The $\mathrm{SV}_{\mathrm{OBS}}$ option clearly underestimates the hydrograph. Peaks are also underestimated with the coupling. In the case of event no. 2, gaps are more reduced. The peak is reproduced in a very satisfactory way with both options. The gaps in terms of Nash ( 0.78 for $\mathrm{SV}_{\mathrm{OBS}}$ vs. 0.61 for $\mathrm{COUPL}_{\mathrm{MOD}}$ ) are hard to see: 
we can barely say that the flood rise and fall are slightly better reproduced with the $\mathrm{SV}_{\mathrm{OBS}}$ option. In the case of event no. 6, this last option is also more satisfactory on flood rise and fall, but less interesting for the reproduction of the peak: the addition of lateral inflows is necessary for its good estimation. Finally, in the case of event no. 7, the $\mathrm{SV}_{\mathrm{OBS}}$ option is the most satisfactory, except for the evaluation of the last peak.

Thus, the $\mathrm{SV}_{\mathrm{OBS}} / \mathrm{COUPL} \mathrm{MOD}_{\mathrm{MOD}}$ comparison ends in contrasted findings according to the events. Nash is improved or equivalent for five events with $\mathrm{SV}_{\mathrm{OBS}}$, which indicates, in these cases, the importance of the quality of modelling upstream to the hydraulic model. The indexes relative to peaks are however often equivalent for both options. Adding lateral inflows appears to be necessary for event nos. 1 and 5, and for the good modelling of the peak of event no. 6 .

\section{Future investigation}

The presented results show that the coupling of models is an interesting tool for the modelling of the hydrographs of the Gardon River at the downstream stations. In this part, some prospection is detailed. This concerns two points in particular: the hydrologic modelling of the ungauged lateral subcatchments, and the use of the coupling in an operating context of water levels and flooded area forecasting.

\subsection{Concerning the SCS-LR hydrologic model parameters of the ungauged inflows}

In this study, the SCS-LR hydrologic model parameters calibrated at Anduze are used for the modelling of the other sub-catchments feeding the hydraulic model, gauged (Alès), or not (the 48 lateral inflows). With this simplified approach, the performances of the coupling are satisfactory at the Ners, Russan and Remoulins stations. However, they could be improved using better adapted parameters.

Naturally, the parameters cannot be calibrated in ungauged catchments. For the lateral inflow modelling, regionalisation approaches of the parameters seem adapted (see examples in Merz and Blöschl, 2004; McIntyre et al., 2005; Parajka et al., 2005; Oudin et al., 2008, 2010; Masih et al., 2010; Garambois, 2012). These methods are based on calibrated parameters at gauged catchments. The literature details three regionalisation approaches:

- The regressive approaches. Regressions between the parameters calibrated on gauged catchments and physical and climatic descriptors are established. The set of parameters of the ungauged catchment is known according to the value of the descriptor of the basin. These methods require a large number of gauged catchments, to cover a wide range of descriptors values.
- The approaches based on spatial proximity. The parameters calibrated on the closest catchments are averaged, then directly used for the targeted ungauged catchment. This approach is based on the hypothesis that nearby catchments have similar hydrological reactions, because they have relative homogeneity of physical and climatic characteristics. It approximates the strategy used in this study.

- The approaches by physical similarity. The sets calibrated on the closest gauged catchments, but in the sense of the physical and climatic characteristics, are averaged then used for the ungauged basin. The similarity between catchments is quantified by means of an index.

According to Oudin et al. (2008), there is still no clear consensus for a preferential regionalisation method. According to Garambois (2012), the regionalisation methods by similarity, defined from soils characteristics, are particularly relevant for catchments of the Cévennes area.

Methods of correction of modelling for ungauged catchments were also developed. Artigue (2012) provides an example, applied to ungauged sub-catchments of the Gardon River basin. The author proposes a correction of his neural network model results by means of a law based on the ungauged basin areas and the estimated maximal specific discharges. This correction strategy allows us to obtain realistic modelling.

These solutions constitute an appropriate way to improve the hydrologic modelling of sub-catchments, and thus the coupling of model results.

\subsection{Use of the coupling for water level and flooded areas forecasting}

As previously evoked, the elaborate coupling of models is a priori adapted for fast flood forecasting. In this section, we indicate the existing approaches to define both parameters of the coupling before the beginning of the event. Then, we detail the modelling of the inundated areas.

The coupling of the models contains two parameters which must be adjusted for each event: $S$ and $V_{0}$. In this study, these two parameters were calibrated, which is obviously impossible in a forecasting context: the values of both parameters must be defined beforehand. For that purpose, the literature describes several possible options. A first approach consists in using one or several state indicators of the catchment, as for example the soil moisture, the base flow, etc. Regressions are established between the parameters calibrated for a range of events and the corresponding indicator values. The parameters for an upcoming event are then known, according to the indicator value of the day. This option was analysed for the $S$ parameter of the SCS-LR model, at the scale of the Gardon d'Anduze catchment (Marchandise and Viel, 2009; Tramblay et al., 2011). These authors show that the 
Table 10. $\mathrm{SV}_{\mathrm{OBS}}$ option results. Performance indexes at the Ners, Russan and Remoulins stations. The symbols on the right of the indexes characterise the gaps compared with the COUPL $\mathrm{MOD}_{\mathrm{M}}$ option. $\downarrow \downarrow$ : deterioration of more than $50 \%$; $\downarrow$ : deterioration of between 5 and $50 \%$; $\uparrow$ : improvement of between 5 and $50 \%$; $\uparrow \uparrow:$ improvement of more than $50 \%$; =: close values, within $\pm 5 \%$. Symbol also attributed to $\mathrm{RE}_{Q m}$, if the absolute difference is lower in $\pm 10 \%$, and for $\Delta T_{Q m}$, if the absolute difference is lower in $\pm 15 \mathrm{~min}$.

\begin{tabular}{|c|c|c|c|c|c|c|c|}
\hline \multirow[t]{2}{*}{ Event } & \multicolumn{3}{|c|}{ Ners } & \multicolumn{3}{|c|}{ Russan } & \multirow{2}{*}{$\begin{array}{l}\text { Remoulins } \\
\Delta T_{Q m}\end{array}$} \\
\hline & Nash & $\mathrm{RE}_{Q m}$ & $\Delta T_{Q m}$ & Nash & $\mathrm{RE}_{Q m}$ & $\Delta T_{Q m}$ & \\
\hline 1 & $0.13 \downarrow \downarrow$ & $-38 \downarrow \downarrow$ & $160 \downarrow \downarrow$ & $-0.10 \downarrow \downarrow$ & $-67 \downarrow \downarrow$ & $-2500 \downarrow \downarrow$ & $-2315 \downarrow \downarrow$ \\
\hline 2 & $0.78 \uparrow$ & $3=$ & $20=$ & $0.85 \uparrow$ & $-7=$ & $-10=$ & $15=$ \\
\hline 3 & $0.96=$ & $0=$ & $15=$ & $0.97=$ & $-10=$ & $-15=$ & $10=$ \\
\hline 4 & $0.89 \uparrow$ & $3=$ & $35=$ & $0.94 \uparrow$ & $-10=$ & $5 \uparrow \uparrow$ & $15=$ \\
\hline 5 & $-1.14 \downarrow \downarrow$ & $-94 \downarrow \downarrow$ & $220 \downarrow \downarrow$ & $-0.75 \downarrow \downarrow$ & $-96 \downarrow \downarrow$ & $480 \downarrow \downarrow$ & $430 \downarrow \downarrow$ \\
\hline 6 & $0.86 \uparrow$ & $-26 \downarrow \downarrow$ & $-590 \downarrow \downarrow$ & $0.77 \uparrow$ & $-39 \downarrow \downarrow$ & $-590 \downarrow \downarrow$ & $-530 \downarrow \downarrow$ \\
\hline 7 & $0.91 \uparrow$ & $8 \uparrow \uparrow$ & $-5 \uparrow \uparrow$ & $0.87 \uparrow$ & $-9=$ & $-45 \uparrow \uparrow$ & $-55 \uparrow \uparrow$ \\
\hline
\end{tabular}
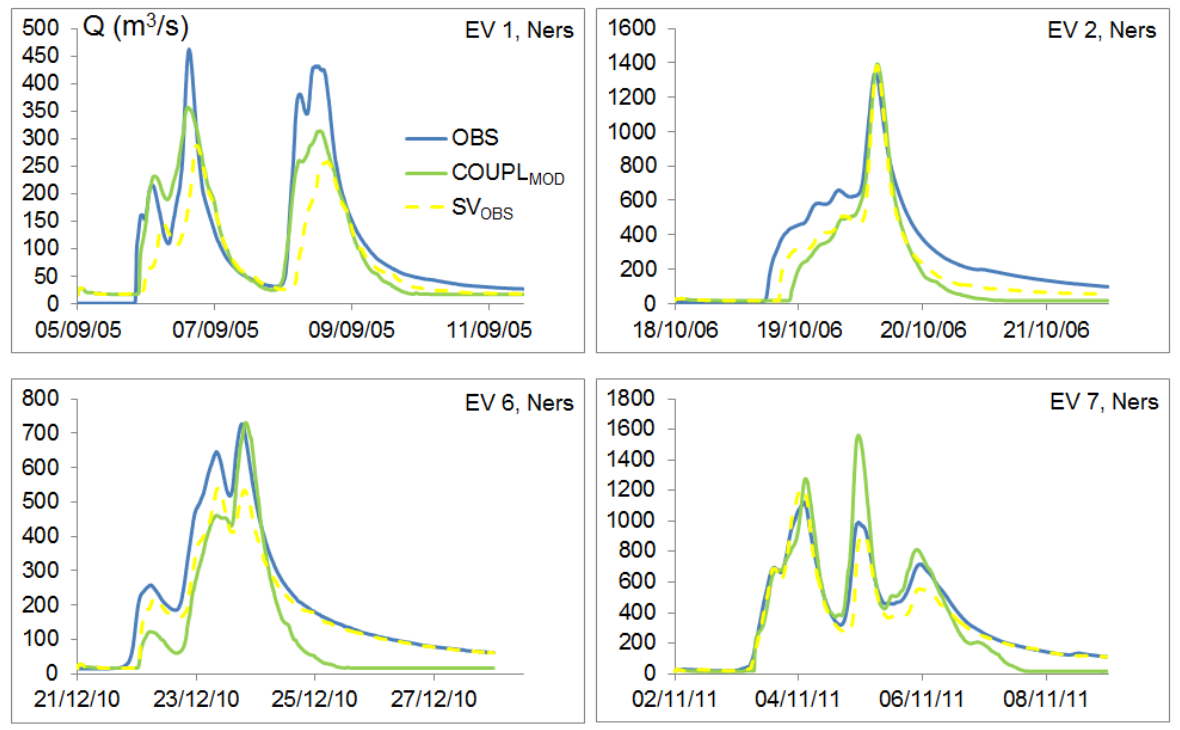

Figure 8. Hydrographs modelled for event nos. 1, 2, 6 and 7 according to the COUPL $\mathrm{MOD}_{\text {and }} \mathrm{SV}_{\mathrm{OBS}}$ modelling options, at the Ners station.

$H u 2$ index calculated every day by the SIM model of MétéoFrance (Habets et al., 2008), and estimating the soil moisture of the root layer (between 10 and $190 \mathrm{~cm}$ ), is particularly interesting for estimating the $S$ parameter.

The data assimilation approach was also developed. An example is described by Coustau (2011) and Coustau et al. (2013). These authors propose assimilation techniques of discharges for the estimation of the $S$ and $V_{0}$ parameters of the SCS-LR model. They show that an assimilation in the first few hours of the flood allows one to obtain parameters that give good results, according to their tests in the Lez River catchment (neighbour of the Gardon River basin). This option is also interesting.

Thus, it would be advisable for use of the coupling in an objective of flood forecasting to predetermine the parameters according to one of these two approaches. These parameters must then be regionalised in the ungauged catchments, as we mentioned earlier.

The coupling is a priori relevant for the modelling of the flooded areas. However, the 1-D hydraulic model in its current form, is little adapted. Indeed, in the floodplain, the flows are strongly multidirectional, and do not satisfy the hypothesis of 1-D flow. For a fine modelling of overflowing, it would be advisable to use a 2-D model, or to complete the 1-D model with storage areas. The choice of a 1-D model rather than a 2-D approach had previously been justified (see Sect. 3.2). The 2-D model requires very fine data, and its calculation times are greater, which is a limiting constraint for a use in operational forecast. Furthermore, studies comparing 1-D and 2-D models, indicate close results with both options, for the modelling of inundated areas (Horritt and Bates, 2002; Aureli et al., 2006; Besnard and Goutal, 2011). However, in the case of the study of Aureli et al. (2006), the 2-D 
model allows a more realistic representation of overflowing during the first hours of the event. Besnard and Goutal (2011) propose a MASCARET model with storage areas, applied to the Garonne river, in the southwest of France. The authors indicate the importance of the links between storages areas, which must be defined in a fine way for the good modelling of overflowing.

Thus, adding storage areas to the hydraulic model appears to be a necessary step for the coupling of models relevant to major events, such as the one of September 2002.

\section{Summary and conclusions}

This study presents the results of a coupling of hydrologic and hydraulic models, used to model the flood hydrographs of the Gardon River. The results were analysed at five hydrometric stations of the catchment, and were compared with those of other modelling options. The used tool is a priori adapted to the modelling of water levels and flooded areas, because of the employment of a 1-D hydraulic model based on the Saint-Venant equations. This capacity of the coupling to model the flooded areas and water levels was not analysed in this study; it was mentioned in Sect. 5.2, and will be the object of future developments.

The results of the coupling in terms of modelling of flood hydrographs are rather satisfactory. At the downstream stations of the catchment, the Nash values are included between 0.61 and 0.97 , reflecting qualities rated as rather good to excellent. The coefficients specific to peak flows are also satisfactory. For most of the studied events, the relative error for peak flow $\left(\mathrm{RE}_{Q m}\right)$ is included between $\pm 15 \%$, and the temporal difference $\left(\Delta T_{Q m}\right)$ is lower than or near $30 \mathrm{~min}$.

The comparison with other modelling strategies allowed us to provide responses to the questions in the introduction and in Sect. 4.2.

The first question focuses on the contribution of a full hydraulic model to the discharge estimation, compared with a simplified lag-and-route routing model. Close results were observed for both options. The coupling is slightly more successful at the Russan station, and even rather clearly for four events. At Ners and Remoulins, both options seem rather equivalent. Thus, a simplified lag-and-route model is suitable for discharge routing in the intermediary downstream part of the Gardon River. However, in contrast to the hydraulic model, it does not allow the estimation of flooded areas.

The second question concerns the interest in adding lateral inflows. For this purpose, the coupling results are compared with those of the $\mathrm{SV}_{\mathrm{MOD}}$ option (hydraulic model without lateral inflows). The gaps between both options differ rather clearly according to events. The rainfall spatial distribution during the event is a key element. When cumulated rainfalls are more important in the intermediary downstream part of the catchment (the case for event nos. 1 and 5, and to a lesser extent for event no. 6), adding lateral inflows is necessary: the coupling is clearly more successful than the $\mathrm{SV}_{\mathrm{MOD}}$ option. On the other hand, when rains are rather centered on sub-catchments upstream of the hydraulic model, the gaps between both options are rather low (the case for event nos. 2 , 3 and 4). Then, the lateral inflows are not necessary. The case of event no. 7 constitutes an interesting feature: it is the only event for which the $\mathrm{SV}_{\mathrm{MOD}}$ option is the most successful. This fact is understandable by an amplification of the errors of both models at upstream entries to the hydraulic model, when lateral inflows are added.

The third question concerns the impact of the qualities of modelling at upstream entries on the hydraulic model. For that purpose, the coupling results are compared with those of the COUPL $L_{O B S}$ option (identical coupling, but with the recorded hydrographs injected at Alès and Anduze). Even there, the rainfall spatial distribution during the event is very influential. The results of both options are very close in the case of event nos. 1 and 5, for which rains were scarce in the upstream, but also for event no. 3. Concerning this last case, the absence of significant improvements is understandable by the very good quality of the hydrologic modelling at Anduze and Alès. The COUPL ${ }_{\mathrm{OBS}}$ modelling is more satisfactory, in terms of Nash, for four other events. These events with heavy rains upstream require good hydrologic modelling upstream. In the cases of event nos. 2, 3 and 4, the differences are however of little significance concerning the $\mathrm{RE}_{Q m}$ and $\Delta T_{Q m}$ indexes.

The comparison with the results of the $\mathrm{SV}_{\mathrm{OBS}}$ option (hydraulic model without lateral inflows, with observed upstream entries), presented in Sect. 4.2.4, also provides some answers as to the interest in adding lateral inflows, and as to the impact of the qualities of the upstream hydrologic modelling. In the case of event nos. 1 and 5, the coupling is clearly more successful than the $\mathrm{SV}_{\mathrm{OBS}}$ option. The $\mathrm{SV}_{\mathrm{OBS}}$ option is more successful, in terms of Nash, for event nos. 2, 4, 6 and 7. The improvements especially concern flood rises and falls. Concerning these four events, the modelling of peaks differs according to both options: the differences are not very notable for event nos. 2 and 4; for event no. 6 , the peak is better modelled with the coupling, whereas in the case of event no. 7 , the $\mathrm{SV}_{\mathrm{OBS}}$ option is more satisfactory.

The coupling results could be improved thanks to better hydrologic modelling of lateral inflows. For this purpose, methods of correction of modelling (Artigue, 2012) or of parameter regionalisation (Garambois, 2012) were estimated for Mediterranean basins, and seem relevant for this studied case.

Finally, this coupling of models turns out to be very interesting for water level and flooded area forecasting. However, the question of the estimation of the coupling parameters before the event is asked. For this purpose, approaches to the assimilation of data (Coustau, 2011; Coustau et al., 2013) or the estimation of the parameters according to state indicators of the catchment (Marchandise and Viel, 2009; Tramblay et al., 2010, 2011) are relevant. Furthermore, the 1-D hydraulic 
model, completed by storage areas, should be very interesting for inundated area modelling during major events, as for the one of September 2002. The continuation of works will address these two aspects.

Acknowledgements. The authors thank Yann Laborda, from SPC-GD, for supplying the hydrological data useful to this study, and for its sensible advice. Thanks are also given to Fabrice Zaoui, from EDF, for his advice relating to the MASCARET code. Thanks to Guy Delrieu, from LTHE (Laboratoire d'étude des Transferts en Hydrologie et Environnement), for supplying the river cross sections necessary for this study. Finally, thanks to Gilles Rocquelain, Fabrice Cebron and Marie-Christine Germain, from BRL Ingénierie, for their advice and remarks.

Edited by: B. Merz

Reviewed by: five anonymous referees

\section{References}

Anquetin, S., Braud, I., Vannier, O., Viallet, P., Boudevillain, B., Creutin, J.-D., and Manus, C.: Sensitivity of the hydrological response to the variability of rainfall fields and soils for the Gard 2002 flash-flood event, J. Hydrol., 394, 134-147, doi:10.1016/j.jhydrol.2010.07.002, 2010.

Artigue, G.: Prévision des crues éclair par réseaux de neurones : généralisation aux bassins non jaugés, Ph.D., Université Montpellier II, Montpellier, France, 318 pp., 2012.

Aureli, F., Mignosa, P., Ziveri, C., and Maranzoni, A.: Fully-2D and quasi-2D modeling of flooding scenarios due to embankment failure, River Flow 2006 - Ferreira, R. M. L., Alves, E. C. T. L., Cardoso, A. H., and Leal, J. G. A. B., Taylor \& Francis Group, London, England, 1473-1482, 2006.

Ayral, P. A., Sauvagnargues-Lesage, S., and Bressand, F.: Contribution à la spatialisation du modèle opérationnel de prévision des crues éclair Alhtaïr, Études de Géographie Physique, 32, 75-97, 2005.

Besnard, A., and Goutal, N.: Comparaison de modèles 1D à casiers et $2 \mathrm{D}$ pour la modélisation hydraulique d'une plaine d'inondation - Cas de la Garonne entre Tonneins et La Réole, Houille Blanche, 3-2011, 42-47, doi:10.1051//hb/2011031, 2011.

Biancamaria, S., Bates, P. D., Boone, A., and Mognard, N. M.: Large-scale coupled hydrologic and hydraulic modelling of the Orb river in Siberia, J. Hydrol., 379, 136-150, doi:10.1016/j.jhydrol.2009.09.054, 2009.

Bonnifait, L., Delrieu, G., Le Lay, M., and Boudevillain, B., Masson, A., Belleudy, P., Gaume, E., and Saulnier, G. M.: Distributed hydrologic and hydraulic modelling with radar rainfall input: reconstruction of the 8-9 September 2002 catastrophic flood event in the Gard region, France, Adv. Water Res., 32, 1077-1089, doi:10.1016/j.advwatres.2009.03.007, 2009.

Bouvier, C., Marchandise, A., Lequien, A., Brunet, P., and Crespy, A.: Distributed rainfall/runoff modelling of September 2002 flood in two southern France river basins, BALWOIS International Scientific Conference, 25-29 May 2004, Ohrid, Republic of Macedonia, 2004.
Bouvier, C., Ayral, P. A., Brunet, P., Crespy, A., Marchandise, A., and Martin, C.: Recent advances in rainfall-runoff modelling: extrapolation to extreme floods in southern France, Proceedings of the AMHY-FRIEND International Workshop on Hydrological Extremes, 3-4 May 2006, University of Calabria, Cosenza, Italy, 229-238, 2006.

Cook, A. and Merwade, V.: Effect of topographic data, geometric configuration and modeling approach on flood inundation mapping, J. Hydrol., 377, 131-142, 2009.

Coustau, M.: Contribution à la prévision des crues sur le bassin du Lez: modélisation de la relation pluie-débit en zone karstique et impact de l'assimilation de débits, Ph.D., Université Montpellier II, Montpellier, France, 234 pp., 2011.

Coustau, M., Ricci, S., Borrell-Estupina, V., Bouvier, C., and Thual, O.: Benefits and limitations of data assimilation for discharge forecasting using an event-based rainfall-runoff model, Nat. Hazards Earth Syst. Sci., 13, 583-596, doi:10.5194/nhess-13583-2013, 2013

Delrieu, G., Ducrocq, V., Gaume, E., Nicol, J., Payrastre, O., Yates, E., Kirstetter, P. E., Andrieu, H., Ayral, P. A., Bouvier, C., Creutin, J. D., Livet, M., Anquetin, S., Lang, M., Neppel, L., Obled, C., Parent-du-Châtelet, J., Saulnier, G. M., Walpersdorf, A., and Wobrock, W.: The catastrophic flood event of 8-9 September 2002 in the Gard region, France: A first case study for the Cévennes-Vivarais Mediterranean Hydrometeorological Observatory, J. Hydrometeorol., 6, 34-52, 2005.

EDF-CETMEF: MASCARET v7.1 Note de principe, Paris, France, 152 pp., 2011.

Garambois, P.A.: Étude régionale des crues éclair de l'arc méditerranéen français; élaboration de méthodologies de transfert à des bassins versants non jaugés, Ph.D., Université de Toulouse, Toulouse, France, 451 pp., 2012.

Gaume, E., Livet, M., Desbordes, M., and Villeneuve, J. P.: Hydrological analysis of the river Aude, France, flash flood on 12 and 13 November 1999, J. Hydrol., 286, 135-154, doi:10.1016/j.jhydrol.2003.09.015, 2004.

Habets, F., Boone, A., Champeaux, J. L., Etchevers, P., Franchistéguy, L., Leblois, E., Ledoux, E., Le Moigne, P., Martin, E., Morel, S., Noilhan, J., Quintana Segui, P., Rousset-Regimbeau, F., and Viennot, P.: The SAFRAN-ISBA-MODCOU hydrometeorological model applied over France, J. Geophys. Res., 113, DO6113, doi:10.1029/2007JD008548, 2008.

Hapuarachchi, H. A. P., Wang, Q. J., and Pagano, T. C.: A review of advances in flash flood forecasting, Hydrol. Process., 25, 27712784, doi:10.1002/hyp.8040, 2011.

Horritt, M. S. and Bates, P. D.: Evaluation of 1D and 2D numerical models for predicting river flood inundation, J. Hydrol., 268, 8799, 2002.

Jacq, V.: Inventaire des situations à précipitations diluviennes sur le Languedoc-Roussillon, la Provence-Alpes-Cote d'Azur et la Corse - Période 1958-1994, Météo-France S3C/PRO, France, 190 pp., 1994.

Kampf, S. and Burges, S. J.: A framework for classifying and comparing distributed hillslope and catchment hydrologic models, Water Resour. Res., 43, W05243, doi:10.1029/2006WR005370, 2007. 
Kim, J., Warnock, A., Ivanov, V. Y., and Katopodes, D.: Coupled modeling of hydrologic and hydrodynamic processes including overland and channel flow, Adv. Water Resour., 37, 104-126, doi:10.1016/j.advwatres.2011.11.009, 2012.

Knebl, M. R., Yang, Z. L., Hutchison, K., and Maidment, D. R.: Regional scale flood modeling using NEXRAD rainfall, GIS, and HEC-HMS/RAS: a case study for the San Antonio River Basin Summer 2002 storm event, J. Environ. Manage., 75, 325-336, doi:10.1016/j.jenvman.2004.11.024, 2005.

Lerat, J.: Quels apports hydrologiques pour les modèles hydrauliques? Vers un modèle intégré de simulation des crues, Ph.D., Université Pierre et Marie Curie, Paris, France, 390 pp., 2009.

Lerat, J., Perrin, C., Andréassian, V., Loumagne, C., and Ribstein, P.: Towards robust methods to couple lumped rainfallrunoff models and hydraulic models: A sensitivity analysis on the Illinois River, J. Hydrol., 418-419, 123-135, doi:10.1016/j.jhydrol.2009.09.019, 2012.

Lian, Y., Chan, I. C., Singh, J., Demissie, M., Knapp, V., and Xie, H.: Coupling of hydrologic and hydraulic models for the Illinois River Basin, J. Hydrol., 344, 210-222, doi:10.1016/j.jhydrol.2007.08.004, 2007.

Linsley, R. K., Kohler, M. A., and Paulhus, J. L. H.: Applied Hydrology, McGraw-Hill, New York, USA, 1949.

Marchandise, A.: Modélisation hydrologique distribuée sur le Gardon d'Anduze; étude comparative de différents modèles pluie-débit, extrapolation de la normale à l'extrême et tests d'hypothèses sur les processus hydrologiques, Ph.D., Université Montpellier II, Montpellier, France, 214 pp., 2007.

Marchandise, A. and Viel, C.: Utilisation des indices d'humidité de la chaîne Safran-Isba-Modcou de Météo-France pour la vigilance et la prévision opérationnelle des crues, Houille Blanche, 6-2009, 35-41, doi:10.1051/lhb/2009075, 2009.

Martin, C.: Les inondations du 15 Juin 2010 dans le centre Var: réflexion sur un épisode exceptionnel, Études de Géographie Physique, 37, 41-76, 2010.

Masih, I., Uhlenbrook, S., Maskey, S., and Ahmad, M. D.: Regionalization of a conceptual rainfall-runoff model based on similarity of the flow duration curve: A case study from the semi-arid Karkheh basin, Iran, J. Hydrol., 391, 188-201, doi:10.1016/j.jhydrol.2010.07.018, 2010.

McCarthy, G. T.: The Unit Hydrograph and flood routing, unpublished manuscript, 1938.

McIntyre, N., Lee, H., Wheater, H., Young, A., and Wagener, T.: Ensemble predictions of runoff in ungauged catchments, Water Resour. Res., 41, W12434, doi:10.1029/2005WR004289, 2005.

Mejia, A. I. and Reed, S. M.: Evaluating the effects of parameterized cross section shapes and simplified routing with a coupled distributed hydrologic and hydraulic model, J. Hydrol., 409, 512-524, doi:10.1016/j.jhydrol.2011.08.050, 2011.

Merz, R. and Blöschl, G.: Regionalisation of catchment model parameters, J. Hydrol., 287, 95-123, doi:10.1016/j.jhydrol.2003.09.028, 2004.

Miller, W. and Cunge, J.: Simplified equations of unsteady flow - Unsteady flow in open channels, in: Vol. 1, Chap. 5, edited by: Mahmood, K. and Yevjevich, V., Water Resour. Publ., Fort Collins, Colorado, 1975.
Montanari, M., Hostache, R., Matgen, P., Schumann, G., Pfister, L., and Hoffmann, L.: Calibration and sequential updating of a coupled hydrologic-hydraulic model using remote sensingderived water stages, Hydrol. Earth Syst. Sci., 13, 367-380, doi:10.5194/hess-13-367-2009, 2009.

Moussa, R. and Bocquillon, C.: On the use of the diffusive wave for modelling extreme flood events with overbank flow in the floodplain, J. Hydrol., 374, 116-135, doi:10.1016/j.jhydrol.2009.06.006, 2009.

Nash, J. E., and Sutcliffe, J. V.: River flow forecasting through conceptual models part I - a discussion of principles, J. Hydrol., 10, 282-290, 1970.

Nelder, J. and Mead, R.: A simplex method for function minimization, Comput. J., 7-4, 308-313, 1965.

Oudin, L., Andréassian, V., Perrin, C., Michel, C., and Le Moine, N.: Spatial proximity, physical similarity, regression and ungaged catchments: A comparison of regionalization approaches based on 913 French catchments, Water Resour. Res., 44, W03413, doi:10.1029/2007WR006240, 2008.

Oudin, L., Kay, A., Andréassian, V., and Perrin, C.: Are seemingly physically similar catchments truly hydrologically similar?, Water Resour. Res., 46, W11558, doi:10.1029/2009WR008887, 2010.

Parajka, J., Merz, R., and Blöschl, G.: A comparison of regionalisation methods for catchment model parameters, Hydrol. Earth Syst. Sci., 9, 157-171, doi:10.5194/hess-9-157-2005, 2005.

Ruin, I., Creutin, J. D., Anquetin, S., and Lutoff, C.: Human exposure to flash floods - Relation between flood parameters and human vulnerability during a storm of September 2002 in Southern France, J. Hydrol., 361, 199-213, doi:10.1016/j.jhydrol.2008.07.044, 2008.

Samuels, P. G.: Cross section location in one-dimensional models, International Conference on river flood hydraulics, 1720 September 1990, Great Britain, 339-350, 1990.

Sangati, M. and Borga, M.: Influence of rainfall spatial resolution on flash flood modelling, Nat. Hazards Earth Syst. Sci., 9, 575584, doi:10.5194/nhess-9-575-2009, 2009.

Sangati, M., Borga, M., Rabuffetti, D., and Bechini, R.: Influence of rainfall and soil properties spatial aggregation on extreme flash flood response modelling: An evaluation based on the Sesia river basin, North Western Italy, Adv. Water Resour., 32, 1090-1106, doi:10.1016/j.advwatres.2008.12.007, 2009.

Saulnier, G. M. and Le Lay, M.: Sensitivity of flash-flood simulations on the volume, the intensity, and the localization of rainfall in the Cévennes-Vivarais region (France), Water Resour. Res., 45, W10425, doi:10.1029/2008WR006906, 2009.

Sauvagnargues-Lesage, S. and Simonet, C.: Retour d'expérience sur la gestion de l'évènement de Septembre 2002 par les Services de la Sécurité Civile, Houille Blanche, 6-2004, 1-7, 2004.

Thierion, V., Ayral, P. A., Geisel, J., Sauvagnargues-Lesage, S., and Payrastre, O.: Grid technology reliability for flash flood forecasting: End-user assessment, J. Grid Comput., 9, 405-422, 2011.

Tramblay, Y., Bouvier, C., Martin, C., Didon-Lescot, J. F., Todorovik, D., and Domergue, J. M.: Assessment of initial soil moisture conditions for event-based rainfall-runoff modeling, J. Hydrol., 387, 176-187, doi:10.1016/j.jhydrol.2010.04.006, 2010. 
Tramblay, Y., Bouvier, C., Ayral, P.-A., and Marchandise, A.: Impact of rainfall spatial distribution on rainfall-runoff modelling efficiency and initial soil moisture conditions estimation, Nat. Hazards Earth Syst. Sci., 11, 157-170, doi:10.5194/nhess-11157-2011, 2011.

Vincendon, B., Ducrocq, V., Saulnier, G. M., Bouilloud, L., Chancibault, K., Habets, F., and Noilhan, J.: Benefit of coupling the ISBA land surface model with a TOPMODEL hydrological model version dedicated to Mediterranean flash-floods, J. Hydrol., 394, 256-266, doi:10.1016/j.jhydrol.2010.04.012, 2010.
Whiteaker, T. L., Robayo, O., Maidment, D. R., and Obenour, D.: From a NEXRAD rainfall map to a flood inundation map, J. Hydrol. Eng., 11, 37-45, doi:10.1061/(ASCE)10840699(2006)11:1(37), 2006.

Zoccatelli, D., Borga, M., Zanon, F., Antonescu, B., and Stancalie, G.: Which rainfall spatial information for flash flood response modelling? A numerical investigation based on data from the Carpathian range, Romania, J. Hydrol., 394, 148-161, doi:10.1016/j.jhydrol.2010.07.019, 2010. 